\title{
Character and Evolution of the Ground-Water Flow System in the Central Part of the Western San Joaquin Valley, California
}

United States Geological Survey Water-Supply Paper 2348

Preparas in conperation with San loaquin valler. Drainage Program

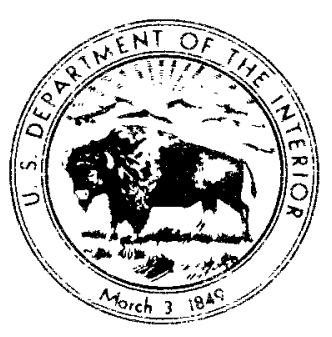




\section{AVAILABILITY OF BOOKS AND MAPS OF THE U.S. GEOLOGICAL SURVEY}

Instructions on ordering publications of the U.S. Geological Survey, along with prices of the last offerings, are given in the current-year issues of the monthly catalog "New Publications of the U.S. Geological Survey." Prices of available U.S. Geological Survey publications released prior to the current year are listed in the most recent annual "Price and Availability List." Publications that are listed in various U.S. Geological Survey catalogs (see back inside cover) but not listed in the most recent annual "Price and Availability List" are no longer available.

Prices of reports released to the open files are given in the listing "U.S. Geological Survey Open-File Reports," updated month1y, which is for sale in microfiche from the U.S. Geological Survey, Books and Open-File Reports Section, Federal Center, Box 25425, Denver, CO 80225. Reports released through the NTIS may be obtained by writing to the National Technical Information Service, U.S. Department of Commerce, Springfield, VA 22161; please include NTIS report number with inquiry.

Order U.S. Geological Survey publications by mail or over the counter from the offices given below.

\section{BY MAIL}

\section{Books}

Professional Papers, Bulletins, Water-Supply Papers, Techniques of Water-Resources Investigations, Circulars, publications of general interest (such as leaflets, pamphlets, booklets), single copies of Earthquakes \& Volcanoes, Preliminary Determination of Epicenters, and some miscellaneous reports, including some of the foregoing series that have gone out of print at the Superintendent of Documents, are obtainable by mail from

\section{U.S. Geological Survey, Books and Open-File Reports Federal Center, Box 25425 Denver, CO 80225}

Subscriptions to periodicals (Earthquakes \& Volcanoes and Preliminary Determination of Epicenters) can be obtained ONLY from the

\section{Superintendent of Documents \\ Government Printing Office \\ Washington, D.C. 20402}

(Check or money order must be payable to Superintendent of Documents.)

\section{Maps}

For maps, address mail orders to

$$
\begin{gathered}
\text { U.S. Geological Survey, Map Distribution } \\
\text { Federal Center, Box } 25286 \\
\text { Denver, CO } 80225
\end{gathered}
$$

Residents of Alaska may order maps from

\author{
Alaska Distribution Section, U.S. Geological Survey, \\ New Federal Building - Box 12 \\ 101 Twelfth Ave., Fairbanks, AK 99701
}

\section{OVER THE COUNTER}

\section{Books}

Books of the U.S. Geological Survey are available over the counter at the following Geological Survey Public Inquiries Offices, all of which are authorized agents of the Superintendent of Documents:

- WASHINGTON, D.C.--Main Interior Bldg., 2600 corridor, 18th and C Sts., NW.

- DENVER, Colorado--Federal Bldg., Rm. 169, 1961 Stout St.

- LOS ANGELES, California--Federal Bldg., Rm. 7638, $300 \mathrm{~N}$. Los Angeles St.

- MENLO PARK, Calffornia--Bldg. 3 (Stop 533), Rm. 3128, 345 Middlefield Rd.

- RESTON, Virginia--503 National Center, Rm. 1C402, 12201 Sunrise Valley Dr.

- SALT LAKE CITY, Utah--Federal Bldg., Rm. 8105, 125 South State St.

- SAN FRANCISCO, California--Customhouse, Rm. 504, 555 Battery St.

- SPOKANE, Washington--U.S. Courthouse, Rm. 678, West 920 Riverside Ave.

- ANCHORAGE, Alaska--Rm. 101, 4230 University Dr.

- ANCHORAGE, Alaska--Federal Bldg, Rm. E-146, 701 C St.

\section{Maps}

Maps may be purchased over the counter at the U.S. Geological Survey offices where books are sold (all addresses in above list) and at the following Geological Survey offices:

- ROLLA, Missouri--1400 Independence Rd.

- DENVER, Colorado--Map Distribution, Bldg. 810, Federal Center

- FAIRBANKS, Alaska--New Federal Bldg., 101 Twelfth Ave. 


\section{Character and Evolution of the Ground-Water Flow System in the Central Part of the Western San Joaquin Valley, California}

By KENNETH BELITZ and FREDERICK J. HEIMES 
DEPARTMENT OF THE INTERIOR

MANUEL LUJAN, JR., Secretary

U.S. GEOLOGICAL SURVEY

Dallas L. Peck, Director

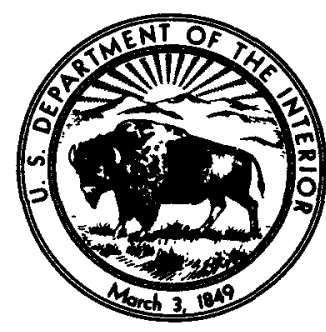

Any use of trade, product, or firm names in this publication is for descriptive purposes only and does not imply endorsement by the U.S. Government

For sale by the

Books and Open-File Reports Section

U.S. Geological Survey

Federal Center, Box 25425

Denver, CO 80225

Library of Congress Cataloging-in-Publication Data

Belitz, Kenneth.

Character and evolution of the ground-water flow system in the central part of the western San Joaquin Valley, California / by Kenneth Belitz and Frederick 1. Heimes.

p. $\quad \mathrm{cm}$. - (Regional aquifer-system analysis) (U.S. Geological Survey water-supply paper ; 2348)

Includes bibliographical references.

Supt. of Docs. no.: I 19.13:2348

1. Groundwater flow-California-San Joaquin River Valley. I. Heimes, Frederick I. II. Title. III. Series. IV. Series: U.S. Geological Survey watersupply paper ; 2348.

GB1197.7.B45 1990

$551.49^{\prime} 09794^{\prime} 8-d c 20$

$90-3650$ 


\section{FOREWORD}

This report was prepared by the U.S. Geological Survey in cooperation with the San Joaquin Valley Drainage Program and as part of the Regional Aquifer-System Analysis (RASA) Program of the U.S. Geological Survey.

The San Joaquin Valley Drainage Program was established in mid-1984 and is a cooperative effort of the U.S. Bureau of Reclamation, U.S. Fish and Wildlife Service, U.S. Geological Survey, California Department of Fish and Game, and California Department of Water Resources. The purposes of the program are to investigate the problems associated with the drainage of agricultural lands in the San Joaquin Valley and to develop solutions to those problems. Consistent with these purposes, program objectives address the following key concerns: (1) public health, (2) surface- and ground-water resources, (3) agricultural productivity, and (4) fish and wildlife resources.

Inquiries concerning the San Joaquin Valley Drainage Program may be directed to:

San Joaquin Valley Drainage Program

Federal-State Interagency Study Team

2800 Cottage Way, Room W-2143

Sacramento, California 95825-1898

The RASA Program of the U.S. Geological Survey was started in 1978 following a congressional mandate to develop quantitative appraisals of the major ground-water systems of the United States. The RASA Program represents a systematic effort to study a number of the Nation's most important aquifer systems, which in aggregate underlie much of the country and which represent an important component of the Nation's total water supply. In general, the boundaries of these studies are identified by the hydrologic extent of each system and accordingly transcend the political subdivisions to which investigations were often arbitrarily limited in the past. The broad objectives for each study are to assemble geologic, hydrologic, and geochemical information, to analyze and develop an understanding of the system, and to develop predictive capabilities that will contribute to the effective management of the system. The Central Valley RASA study, which focused on the hydrology and geochemistry of ground water in the Central Valley of California, began in 1979. Phase II of the Central Valley RASA began in 1984 and is in progress. The focus during this second phase is on more detailed study of the hydrology and geochemistry of ground water in the San Joaquin Valley, which is the southern half of the Central Valley.

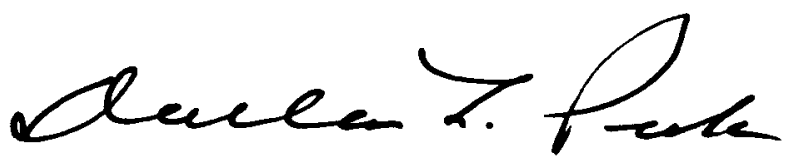

Dallas L. Peck

Director 


\title{
CONTENTS
}

\author{
Foreword III \\ Abstract 1 \\ Introduction 1 \\ Background 1 \\ Purpose and scope 1 \\ Previous investigations 2 \\ Acknowledgments $\mathbf{3}$
}

Geology 3

Ground-water flow system 7

Predevelopment flow system $\mathbf{8}$

Agricultural development and system response 12

Configuration of water table in $1984 \quad 21$

Vertical gradients $\mathbf{2 5}$

Generalized geohydrologic section through flow system 25

Conclusions 26

References cited 27

\section{FIGURES}

1-9. Maps showing:

1. Location and topography of study area 2

2. Thickness of Coast Ranges alluvium that overlies the Corcoran Clay Member of the Tulare Formation 4

3. Thickness and extent of Sierran sand 5

4. Surficial geology 6

5. Depth to base of the Corcoran Clay Member of the Tulare Formation 7

6. Thickness of the Corcoran Clay Member of the Tulare Formation 8

7. Distribution of alkali in soils 9

8. Boundaries of near-surface subsidence areas $\mathbf{1 0}$

9. Estimated water-table altitude and extent of artesian areas, $1908 \mathbf{1 1}$

10. Graph showing ground-water pumpage and total available water, Westlands Water District, 1935-85 12

11-19. Maps showing:

11. Extent of areas irrigated with ground water and surface water, 1912-55 12

12. Potentiometric surface of confined zone, $1952 \quad 13$

13. Water-table altitude, spring $1952 \quad 14$

14. Potentiometric surface of confined zone, December $1967 \quad 15$

15. Land subsidence, $1926-72 \quad 16$

16. Potentiometric surface of confined zone, spring $1984 \quad 17$

17. Depth to water table, spring 195218

18. Depth to water table, October 198419

19. Wells used to map depth to and altitude of water table, October $1984 \quad 20$

20. Hydrographs of two wells drilled to different depths in semiconfined zone 21

21. Map showing location of area serviced by regional tile-drain system and area of approximately equivalent size, topographic relief, and geomorphic character 22

22. Hydrographs of eight wells along approximate flow line $\mathbf{2 3}$

23. Map showing water-table altitude, October 198424

24. Generalized geohydrologic section through flow system 26 


\section{METRIC CONVERSION FACTORS}

For readers who prefer to use metric (International System) units rather than inch-pound units (used in this report), the following conversion factors may be applied:

\begin{tabular}{rll}
\hline Multiply inch-pound unit & By & To obtain metric unit \\
acre & 0.4047 & square hectometer \\
acre-foot per year & 0.001234 & cubic hectometer per year \\
foot & 0.3048 & meter \\
foot per mile & 0.1894 & meter per kilometer \\
cubic foot per year per square foot & 0.3048 & cubic meter per annum per square meter \\
mile & 1.609 & kilometer \\
square mile & 2.590 & square kilometer \\
\hline
\end{tabular}

\section{ALTITUDE DATUM}

Sea level: In this report "sea level" refers to the National Geodetic Vertical Datum (NGVD) of 1929 - a geodetic datum derived from a general adjustment of the first-order level nets of both the United States and Canada, formerly called Sea Level Datum of 1929. 


\section{Character and Evolution of the Ground-Water Flow System in the Central Part of the Western San Joaquin Valley, California}

\author{
By Kenneth Belitz and Frederick J. Heimes
}

\section{Abstract}

The occurrence of selenium in agricultural drain water derived from the western San Joaquin Valley, California, has focused concern on the ground-water flow system of the western valley. In this investigation, previous work and recently collected texture and water-level data are used to evaluate the character and evolution of the regional ground-water flow system in the central part of the western valley, with particular emphasis on the deposits overlying the Corcoran Clay Member of the Tulare Formation.

The Corcoran Clay Member, where present, divides the flow system into an upper semiconfined zone and a lower confined zone. Above the Corcoran, three hydrogeologic units can be recognized: Coast Ranges alluvium, Sierran sand, and flood-basin deposits. These units differ in texture, hydrologic properties, and oxidation state.

The development of irrigated agriculture in the central part of the western valley has significantly altered the flow system. Percolation of irrigation water past crop roots has caused a rise in the altitude of the water table in midfan and distal-fan areas. Pumpage of ground water from wells has caused a lowering of the water table beneath parts of the fanheads and a lowering of the potentiometric surface of the confined zone over much of the western valley. The combination of percolation and pumpage has resulted in development of a large downward hydraulic-head gradient in the semiconfined zone and has created a ground-water divide. Surface-water deliveries from the California Aqueduct have allowed a decrease in pumping and a consequent recovery in hydraulic head throughout the system.

\section{INTRODUCTION}

\section{Background}

Saline conditions and associated high levels of selenium and other soluble trace elements are prevalent in soils,

Manuscript approved for publication, October 29, 1987. ground water, and agricultural drain water of the western San Joaquin Valley, California (Deverel and others, 1984; Tidball and others, 1986). The occurrence and movement of selenium and other dissolved constituents through the hydrologic system of the western valley is closely related to the movement of ground water. Therefore, an understanding of the ground-water flow system provides insight into the sources, occurrence, and movement of selenium and other solutes in the system. In addition, an increased understanding of the ground-water flow system provides resource managers with information that is helpful in managing the system.

\section{Purpose and Scope}

The objective of this report is to present an overview of the ground-water flow system in the central part of the western San Joaquin Valley, with particular emphasis on the deposits and flow system above the Corcoran Clay Member of the Tulare Formation. The primary study area is shown in figure 1, though some information given in this report extends beyond those boundaries.

The study area includes those parts of the western valley containing the highest levels of selenium in soil (Tidball and others, 1986), ground water, and agricultural drain water (Deverel and others, 1984). Although several reports have been written on the ground-water hydrology of the western valley, few focused on the flow system in the deposits that overlie the Corcoran. Moreover, the flow system has undergone considerable change since those reports were written. The present investigation synthesizes previous work with ongoing investigations to describe (1) the geology of the regional flow system, (2) the evolution of the flow system since the development of irrigated agriculture, and (3) the present-day flow system. Such a synthesis provides valuable information to current investigators and planners and serves as a foundation for subsequent quantitative studies of the flow system at both local and regional scales.

This study is part of a comprehensive investigation by the U.S. Geological Survey of the hydrology and geochem- 
istry of the San Joaquin Valley. The work is part of the Regional Aquifer-System Analysis (RASA) Program of the U.S. Geological Survey and is being done in cooperation with the San Joaquin Valley Drainage Program.

\section{Previous Investigations}

Several earlier geologic and hydrologic studies focused on or included the central part of the western San
Joaquin Valley. Davis and Poland (1957) recognized three bodies of ground water in the western San Joaquin Valley: (1) an unconfined and semiconfined zone of freshwater above the Corcoran Clay Member of the Tulare Formation, (2) a confined zone of freshwater beneath the Corcoran Clay Member, and (3) a saline body of water underlying the confined freshwater. Davis and Poland (1957) and Davis and others (1959) noted that the deposits overlying the Corcoran Clay Member are derived from the Coast Ranges to the west and the Sierra Nevada to the east. Miller and

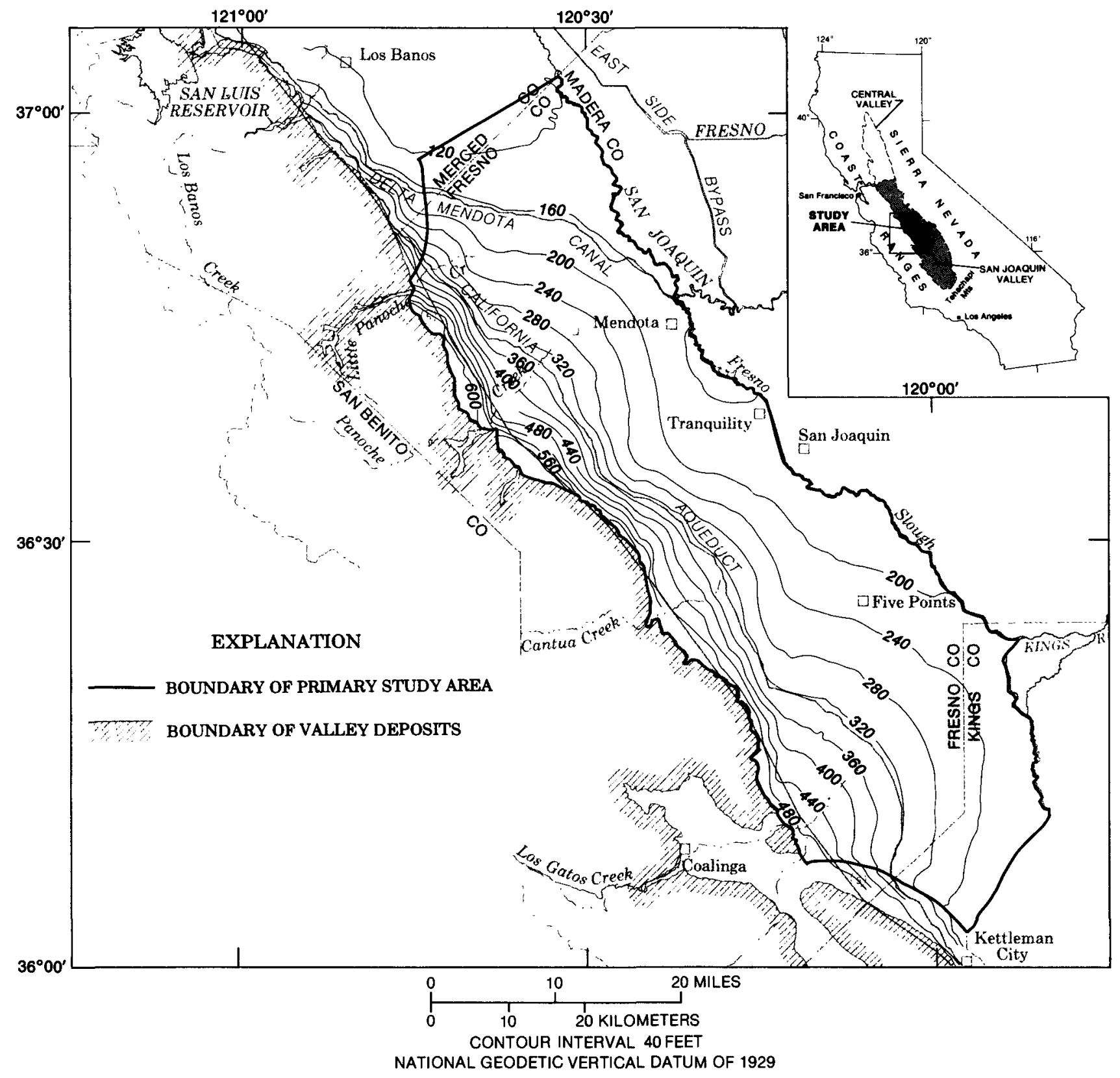

Figure 1. Location and topography of study area. 
others (1971) mapped the thickness and extent of the deposits derived from each of these sources. Miller and others (1971) and Bull and Miller (1975) noted that the deposits which are derived from the Coast Ranges and overlie the Corcoran are typically of low permeability and those derived from the Sierra Nevada are generally of higher permeability. Historically, agricultural wells in the western valley primarily tapped the confined zone except in the valley trough, where the wells also tapped deposits derived from the Sierra Nevada. The geology of the freshwater-bearing deposits was extensively discussed by Miller and others (1971), Croft (1972), Hotchkiss (1972), and Page (1986).

Several previous studies assessed the ground-water flow system at a particular period in time. The earliest assessment of ground water in the western valley was done by Mendenhall (1908) and by Mendenhall and others (1916). Their published work provides documentation of the system during the earliest stages of agricultural development. Davis and Poland (1957) and Davis and others (1959) provide documentation of the flow system during a period of rapid expansion of irrigated acreage. These authors used the work of Mendenhall and others (1916) to assess the natural flow system and evaluate the changes in the natural system resulting from agricultural development. Bull and Miller (1975) also investigated changes in the flow system arising from agricultural development and related those changes to land subsidence. The U.S. Bureau of Reclamation (1965) prepared maps, cross sections, and hydrographs, which document the geology and hydrology prior to the completion of the California Aqueduct. Hotchkiss and Balding (1971) assessed the geology, hydrology, and water quality of the freshwater-bearing deposits in the northern part of the western valley. Ireland and others (1984) presented a large number of maps and hydrographs that document water levels and the evolution of the flow system.

Most recently, Williamson (1982), Diamond and Williamson (1983), and Williamson and others (1989) conducted a comprehensive investigation of the flow system for the entire Central Valley. That study, which was part of the RASA Program of the U.S. Geological Survey, assessed the flow system in the Central Valley under natural conditions and for 1961-77.

\section{Acknowledgments}

The preparation and completion of this report were made possible by the cooperation and assistance of several agencies. The U.S. Bureau of Reclamation, the California Department of Water Resources, and the Westlands Water District provided data and maps essential to this investigation.

\section{GEOLOGY}

The San Joaquin Valley is an asymmetrical basin bounded by the Coast Ranges on the west, the Tehachapi Mountains on the south, the Sierra Nevada on the east, and the delta of the San Joaquin and Sacramento Rivers on the north. The axis of the valley trough is closer to the Coast Ranges than to the Sierra Nevada. The study area shown in figure 1 is defined by the Coast Ranges on the west, by the San Joaquin River and Fresno Slough in the trough of the San Joaquin Valley on the east, and by the lateral extent of prominent alluvial fans derived from the Coast Ranges on the north and south.

Bull (1964a, b; 1972) identified 21 alluvial fans in western Fresno County ranging in area from less than 1 square mile to more than 250 square miles. Deposits associated with the two largest fans, Los Gatos Creek fan and Panoche Creek fan, occupy more than one-half of western Fresno County. Many of the fans identified by Bull are of limited areal extent and coalesce with large neighboring fans.

The Pleistocene Corcoran Clay Member of the Tulare Formation, where present, divides the ground-water flow system into a lower confined zone and an upper semiconfined zone. The deposits of the semiconfined zone can be divided into three hydrogeologic units that differ in texture, hydrologic properties, and oxidation state: Coast Ranges alluvium, Sierran sand, and flood-basin deposits.

The Coast Ranges alluvium is derived from the Coast Ranges to the west. The alluvial deposits are generally oxidized (Davis and others, 1959) and range in thickness from 850 feet (Page, 1986) along the Coast Ranges to 0 feet along the valley trough (fig. 2). The texture of the alluvium is largely a function of relative position on the alluvial fan. Alluvial fans are commonly divided into three parts (Blissenbach, 1954; Reineck and Singh, 1980): the fanhead (the apex of the alluvial fan), the midfan (the area between the fanhead and the lower margins of the fan), and the distal fan (the outermost, lowest altitudes of the fan, where the fan often coalesces with other fans). The deposits are significantly coarser at the fanhead than at the midfan and distal-fan locations. Textural analysis of the alluvial deposits (Laudon and Belitz, 1989) indicated that the fanhead deposits are typically 80 to 100 percent sand plus gravel and less than 20 percent silt plus clay. The distal-fan deposits typically contain less than 20 percent sand plus gravel and more than 80 percent silt plus clay. The midfan deposits are typically coarse textured along present-day stream channels and paleochannels and finer grained between channels.

Bull (1964b) recognized two types of deposits in the alluvium: mudflow and water-laid deposits. The mudflow deposits typically are poorly sorted and are in close proximity to the Coast Ranges. The water-laid deposits are better sorted and are more areally extensive than the mudflow deposits. 
The alluvium derived from the Coast Ranges interfingers eastward with material derived from the Sierra Nevada to the east. In the trough of the valley, the deposits derived from the Sierra Nevada are predominantly wellsorted micaceous sand (Miller and others, 1971). The Sierran sand is 400 to 500 feet thick in the valley trough and thins eastward and westward (fig. 3). The Sierran sand differs from the Coast Ranges alluvium in texture as well as oxidation state. In contrast to Coast Ranges alluvium, the
Sierran sand is reduced in the valley trough (Davis and others, 1959). The Sierran deposits are highly permeable and historically have been tapped by wells as a source of irrigation water.

In the valley trough, the Sierran sand is overlain by a veneer of flood-basin deposits (fig. 4). The basin deposits are derived from the Coast Ranges to the west and the Sierra Nevada to the east. The deposits are of variable thickness (typically 5 to 35 feet) and texture but consist primarily of

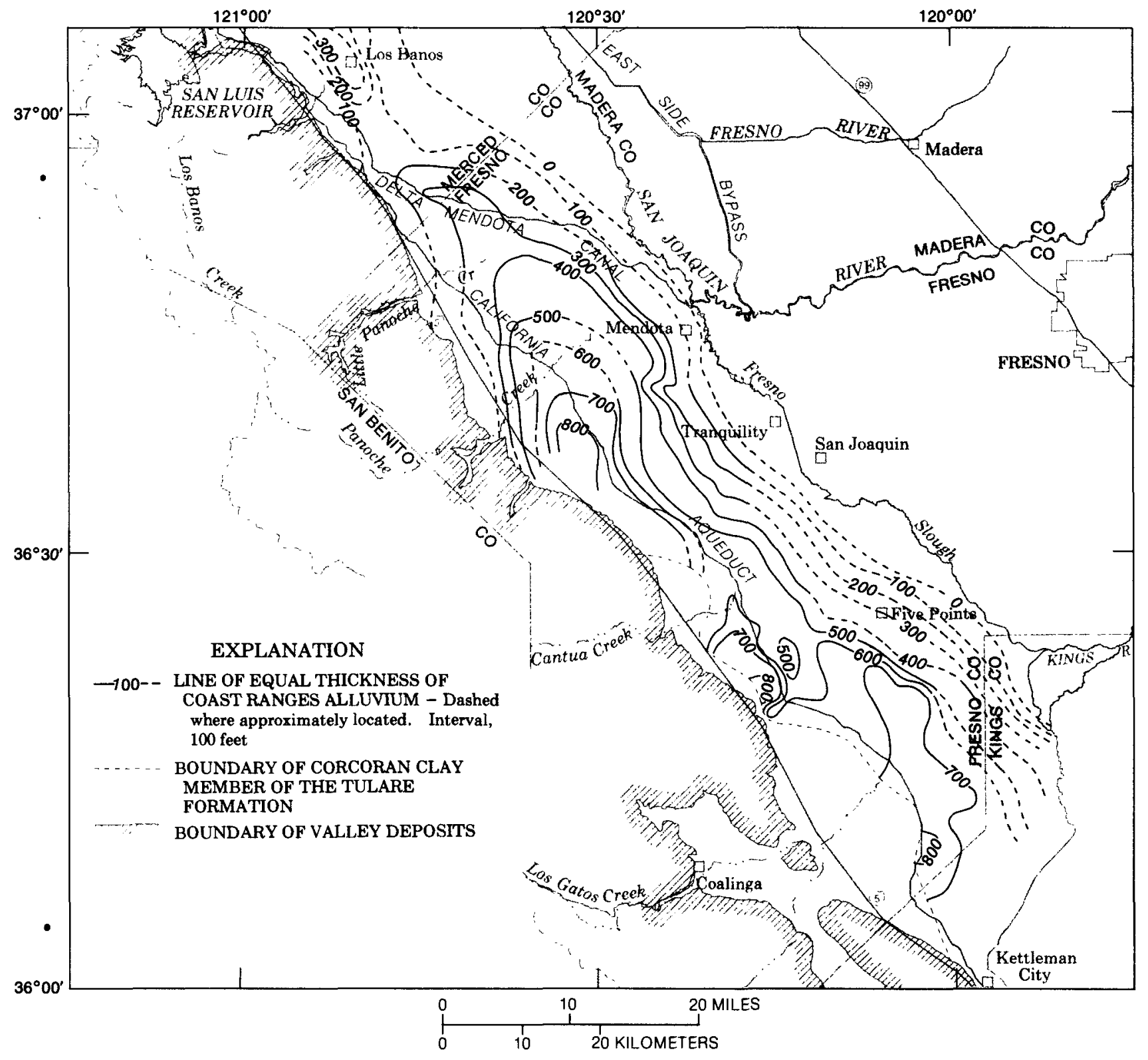

Figure 2. Thickness of Coast Ranges alluvium that overlies the Corcoran Clay Member of the Tulare Formation. (Modified from Miller and others, 1971.) 
fine-textured, moderately to densely compacted clays. The basin clays have low permeability and greatly impede the downward movement of water. The oxidation state of the flood-basin deposits is uneven, reflecting the variability of depositional conditions and perhaps changes in oxidation state attributable to agricultural activity.

An understanding of the flow system above the Corcoran Clay Member of the Tulare Formation requires, to a certain extent, an understanding of the Corcoran and of the flow system below the Corcoran. The Corcoran Clay Member is an extensive lacustrine deposit of low permeability (Johnson and others, 1968). The base of the unit ranges in depth from 400 feet in the valley trough to more than 900 feet along the Coast Ranges (fig. 5), and the unit ranges in thickness from 20 to 120 feet (fig. 6). Although the recent mapping of the Corcoran Clay Member by Page (1986) confirmed the general structural trends and thickness data depicted in figures 5 and 6 , his work revealed greater

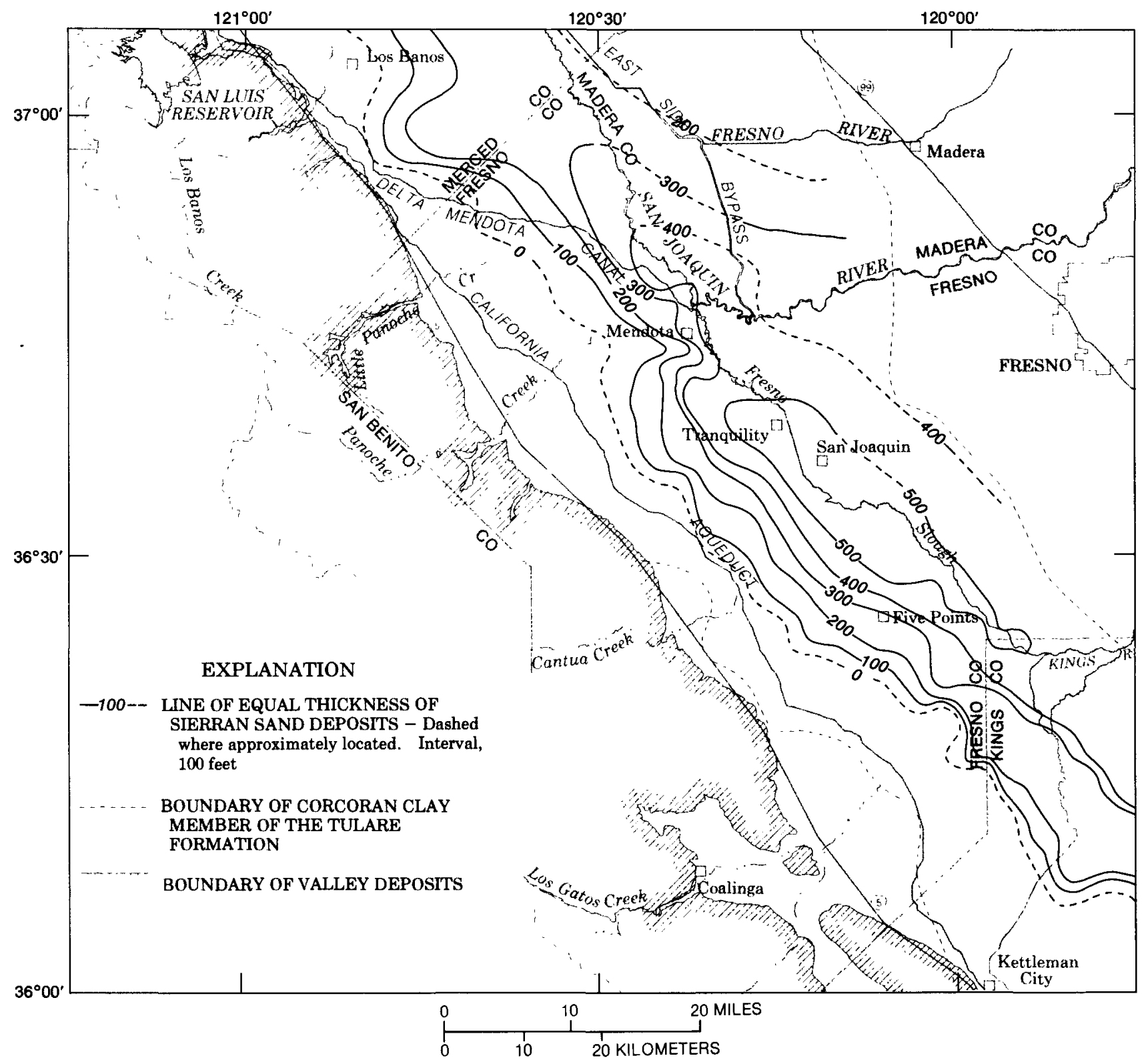

Figure 3. Thickness and extent of Sierran sand. (Modified from Miller and others, 1971.) 
variability than the earlier studies (Miller and others, 1971; Bull and Miller, 1975) had suggested. The upper two-thirds of the Corcoran Clay Member consists of thin-bedded clayey silt and silty clay and the lower one-third consists of interbedded sand-silt-clay and clayey silt (Bull, 1975). The Corcoran is chemically reduced except in the extreme western part of the study area where it has been uplifted and partially oxidized.
Historically, many of the agricultural production wells in the study area were perforated below the Corcoran Clay Member. The lower confined zone consists of poorly consolidated flood-plain, deltaic, alluvial-fan, and lacustrine deposits of the Tulare Formation. This zone was the subject of numerous investigations, many of which focus on land subsidence (for a review, see Poland and others, 1975).

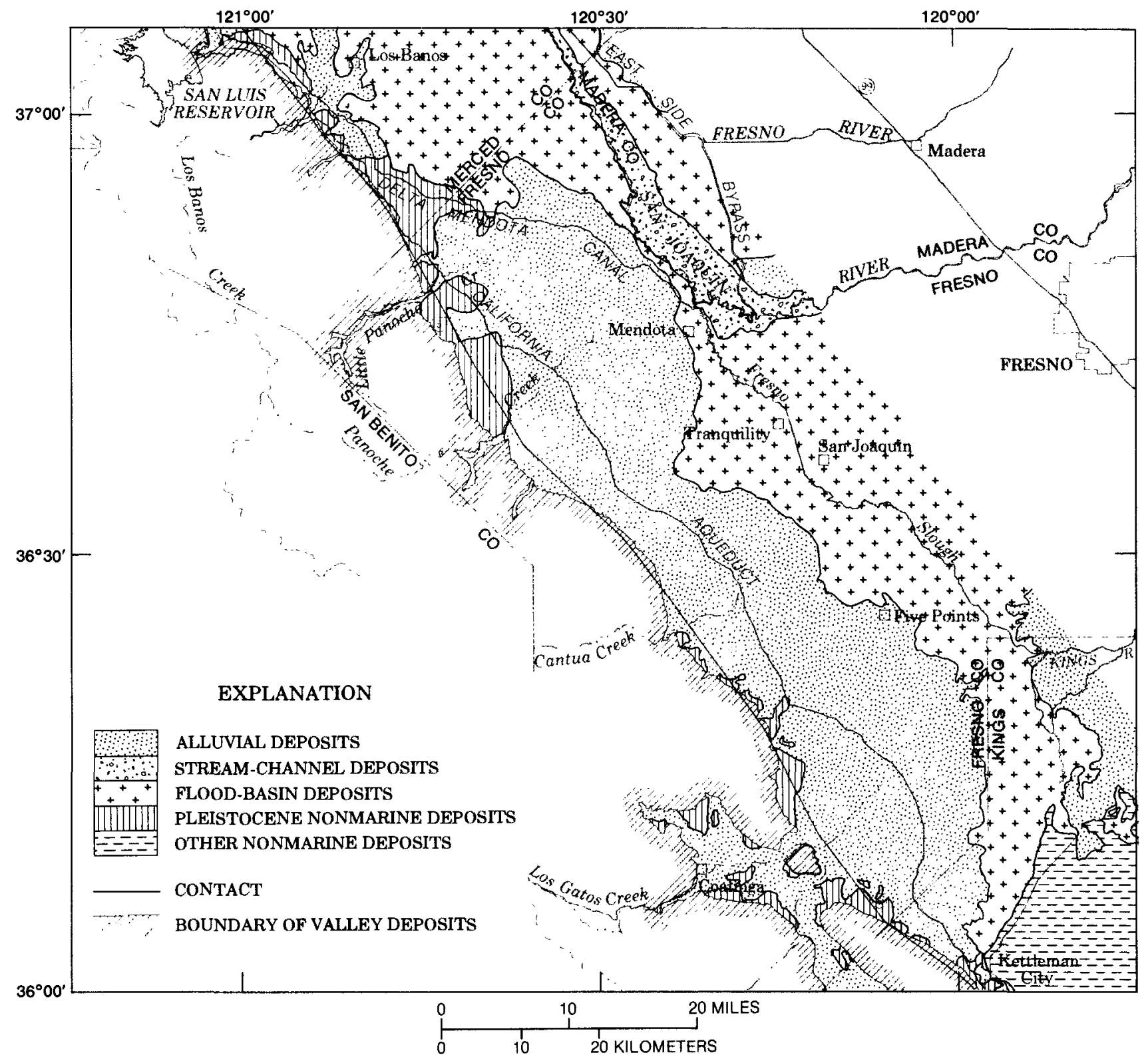

Figure 4. Surficial geology. (Modified from California Division of Mines and Geology, 1959, 1965, and 1966). 


\section{GROUND-WATER FLOW SYSTEM}

The ground-water flow system of the western San Joaquin Valley has undergone considerable change since the development of irrigated agriculture. The present-day flow system is in a transient state and is responding to stresses imposed on it in both the past and the present. Therefore, it is useful to understand the natural flow system and the evolution of the flow system since the development of irrigated agriculture in the western valley. Because the focus of this paper is on the semiconfined zone, it is of particular importance to understand the activities that have affected the semiconfined zone. These activities include percolation of irrigation water past crop roots, historical pumping of ground water from below the Corcoran Clay Member of the Tulare Formation, delivery of surface water, and installation of a regional subsurface tile-drain system. As will be discussed in the following sections, the response

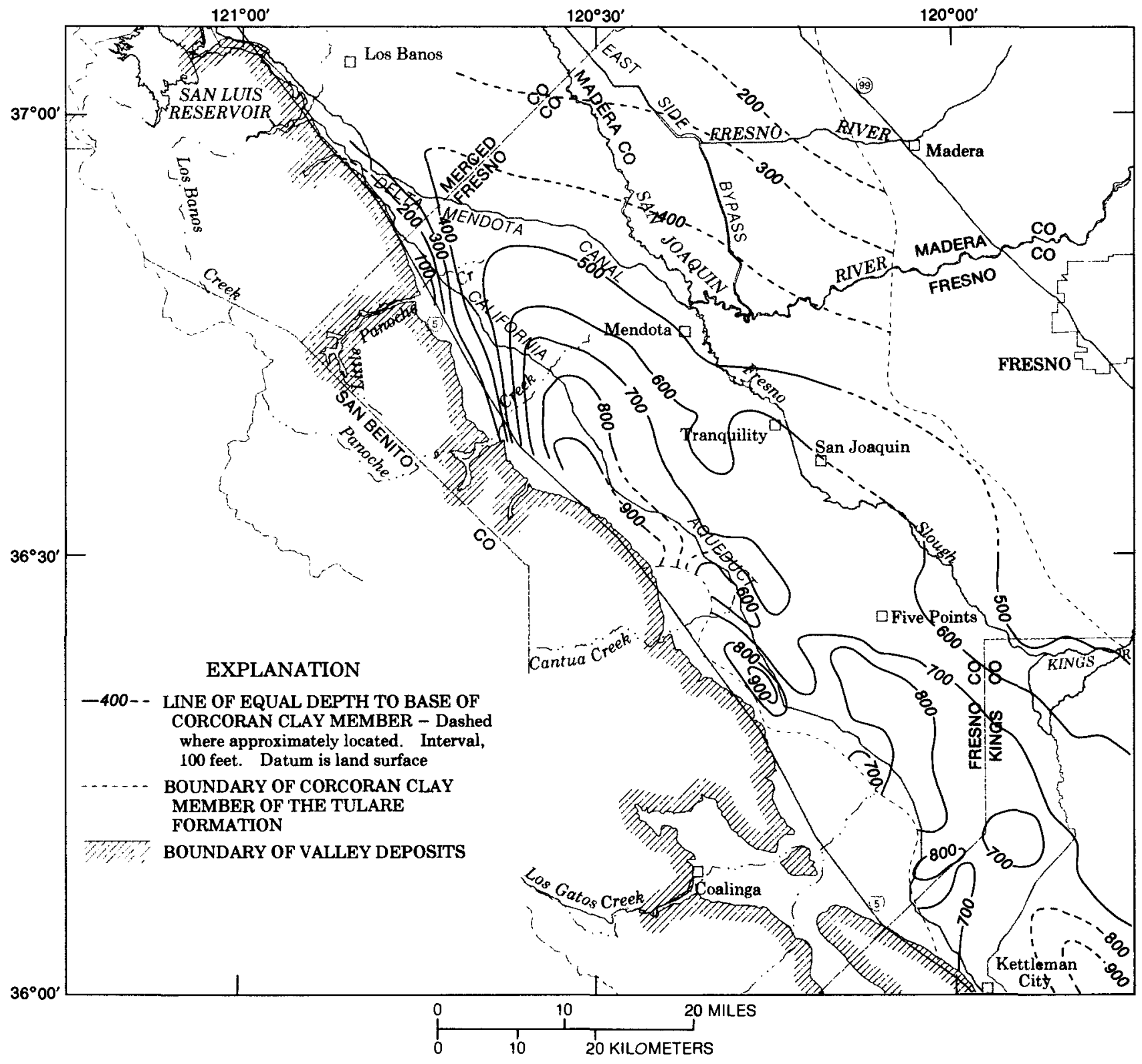

Figure 5. Depth to base of the Corcoran Clay Member of the Tulare Formation. (Modified from Bull and Miller, 1975). 
of the semiconfined zone to these activities is partly dependent on the texture of the subsurface deposits.

\section{Predevelopment Flow System}

Under natural conditions, recharge was primarily from infiltration of stream water from intermittent streams and, perhaps, from smaller ephemeral streams. The intermittent streams (Little Panoche, Panoche, Cantua, and Los
Gatos Creeks) flow seasonally during the winter rainy season and the smaller ephemeral streams flow only after storms (Bull, 1964a). None of the stream courses reach the San Joaquin River or Fresno Slough in the trough of the valley. The streams lose their flow through evaporation and infiltration before reaching the valley floor. Davis and Poland (1957) estimated that the four intermittent creeks typically have a total flow of about 50,000 acre-feet per year of which 30,000 to 40,000 acre-feet per year infiltrates

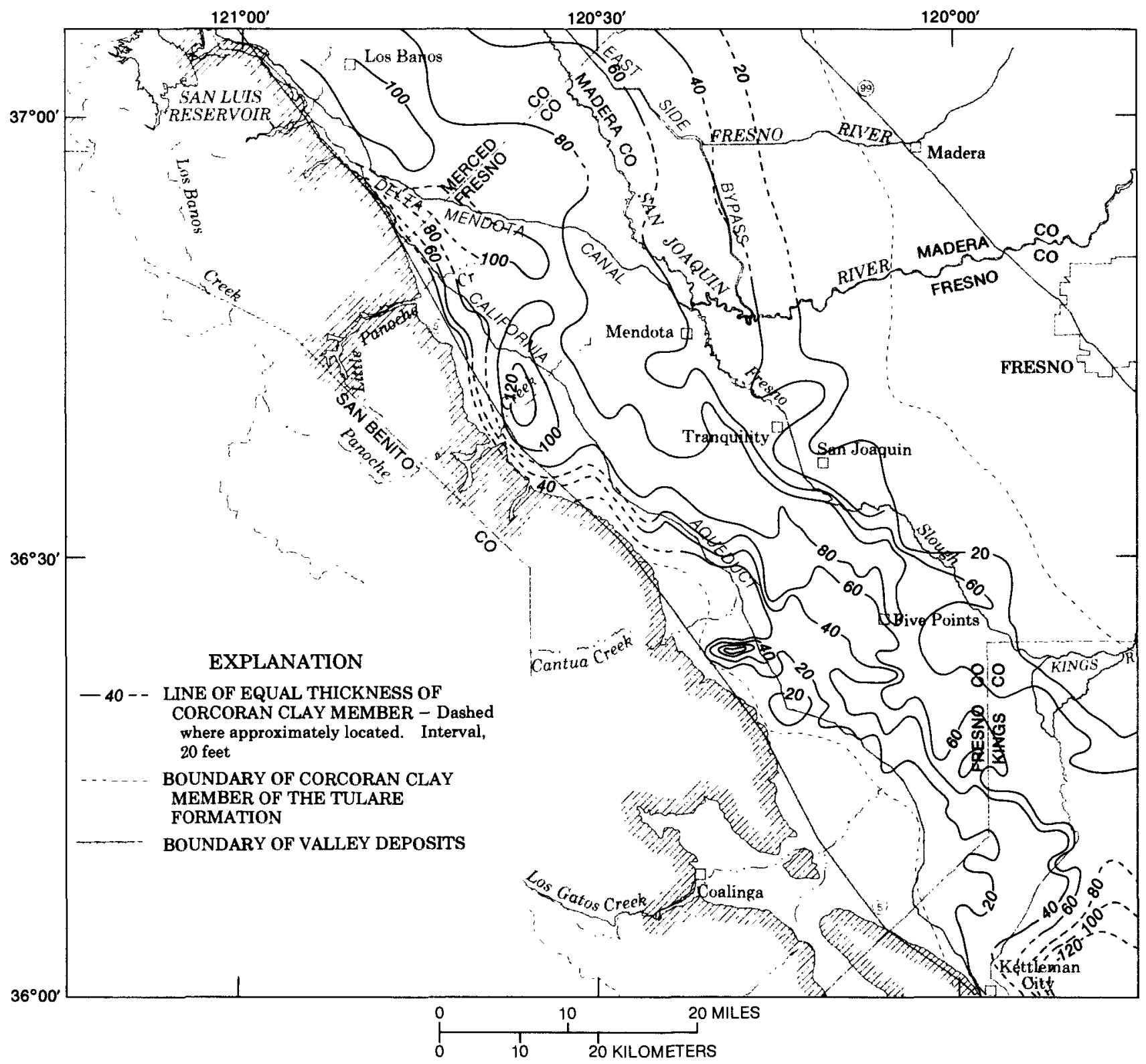

Figure 6. Thickness of the Corcoran Clay Member of the Tulare Formation. (Modified from Miller and others, 1971.) 
and recharges the ground water. Davis and Poland (1957) and subsequent workers assumed that rainfall was an insignificant mechanism for recharging the system under natural conditions.

Soil-salinity and soil-compaction data support the view that natural recharge was limited primarily to areas traversed by the intermittent streams. A soil-salinity map prepared by Harradine (1950; fig. 7 ) indicates that the highest soil salinities are associated with the midfan and distal-fan areas, which historically were not traversed by intermittent streams. The lowest soil salinities are associated with the fanhead and midfan areas where they are traversed by the major creeks. The absence of saline soils along the contact between the Coast Ranges and the alluvium along much of the western valley indicates that the numerous minor drainages may have contributed recharge to the ground-water flow system in the geologic past. In contrast, the distribution of soils that were or are susceptible

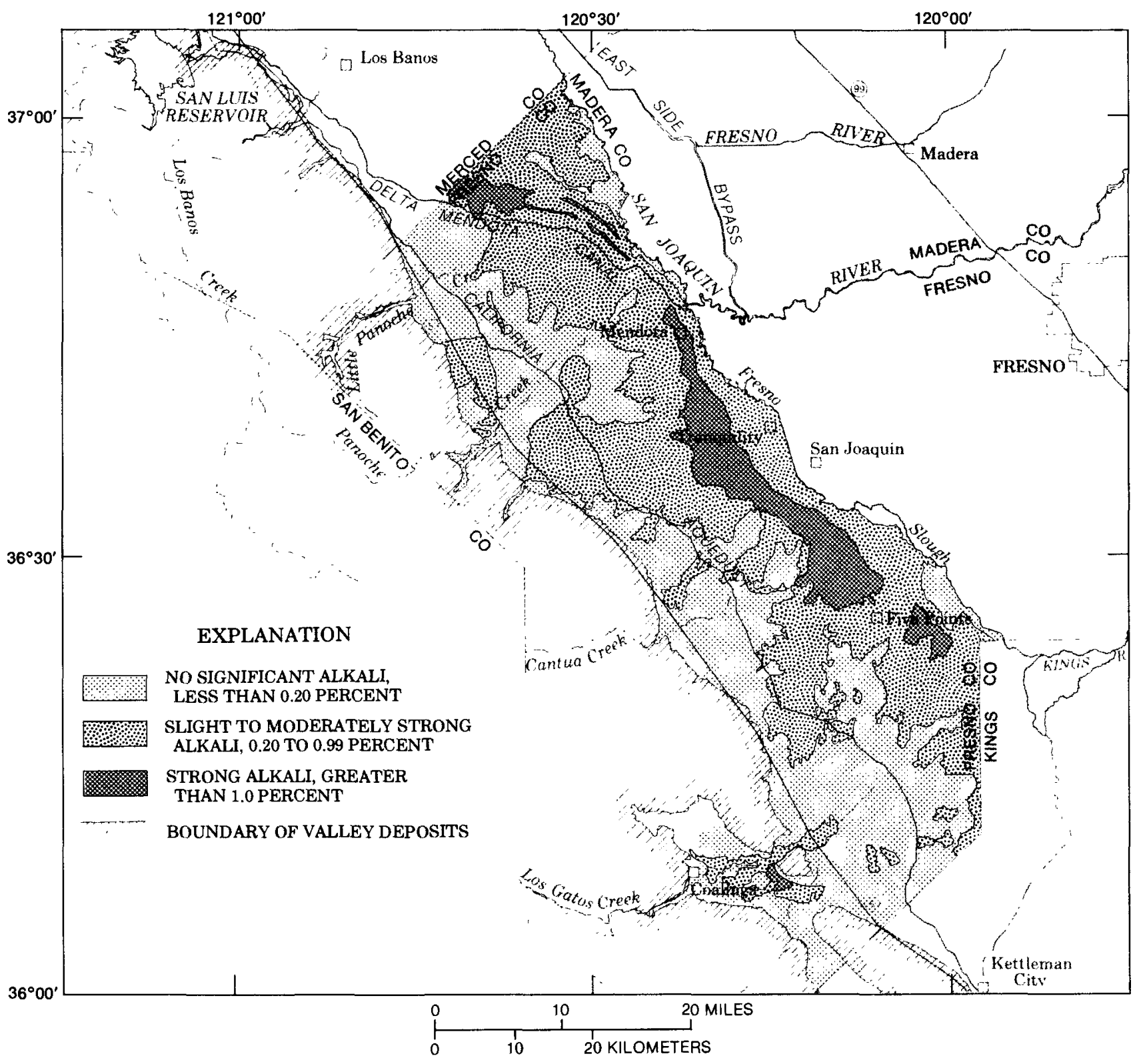

Figure 7. Distribution of alkali in soils. (Modified from Harradine, 1950.) 
to near-surface subsidence resulting from soil compaction due to application of water at the surface (fig. 8) indicates that recharge was small in the areas between the large alluvial fans of the intermittent creeks. Bull (1964b) noted that the interfan areas were built up from mudflow deposits, which are subject to compaction when wetted. The presence of deposits compacted prior to agricultural development in the fanhead areas and of deposits that were or could be compacted as a result of irrigation in the interfan areas suggests that, under natural conditions, recharge occurred at the fanheads and did not occur in the interfan areas.

Discharge from the system under natural conditions was primarily by evapotranspiration and streamflow along the valley trough. Early geologic surveys of the valley (Hamilton, 1916) indicate the presence of marshland along most of the valley trough. Mendenhall and others' (1916) map of water levels in the semiconfined zone (fig. 9) indicates that artesian conditions prevailed along a broad

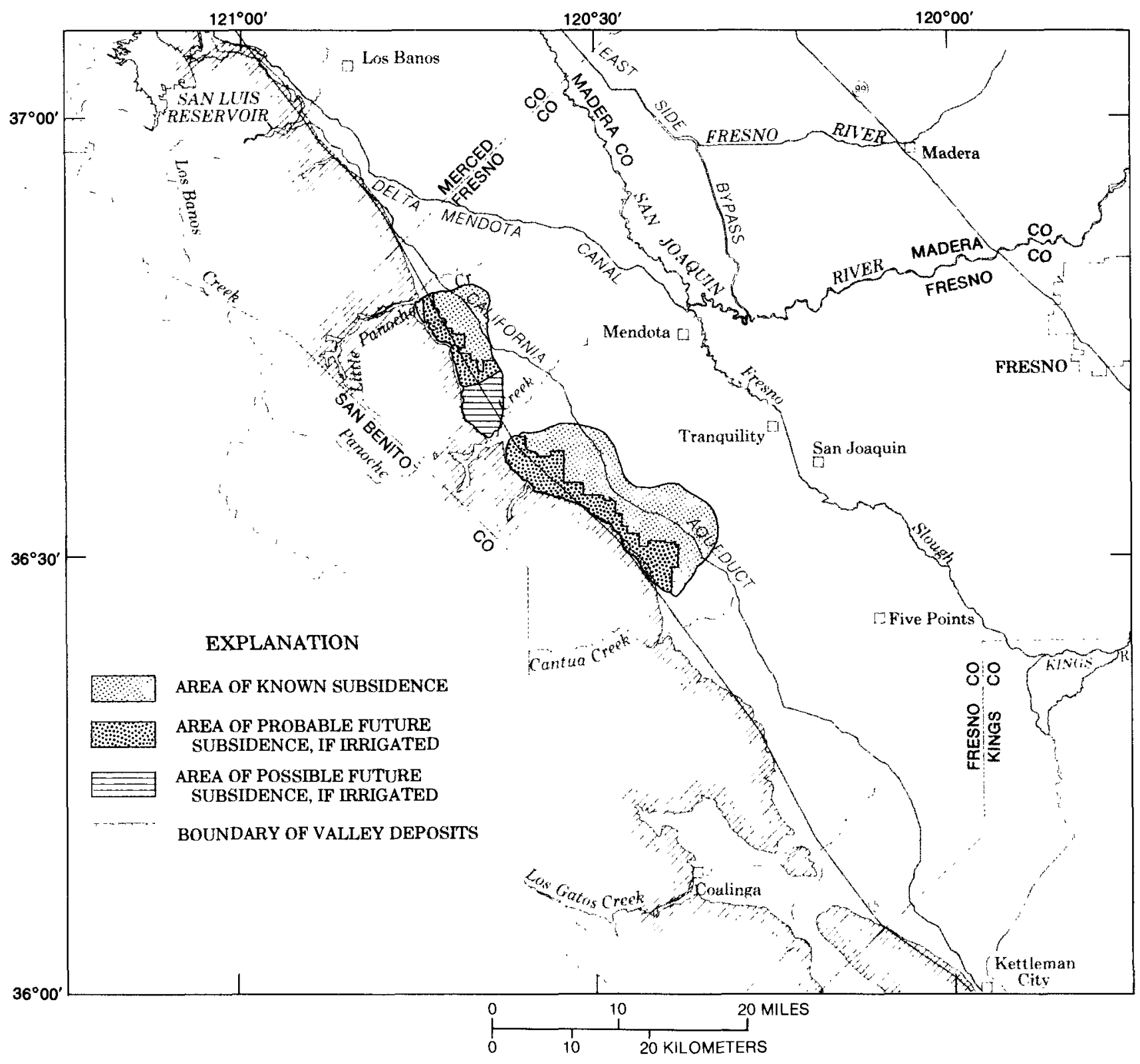

Figure 8. Boundaries of near-surface subsidence areas. (Modified from Bull, 1964b.) 
stretch of the valley trough. The presence of marshland in the arid to semiarid Central Valley and the extensive artesian conditions indicate that the valley trough was a discharge area under predevelopment conditions.

The map by Mendenhall and others (1916) indicates that ground-water gradients in the semiconfined zone were from the southwest to the northeast, reflecting the general topographic trend of the area. Gradients typically were 1 to 3 feet per mile, reflecting the arid climate and low rates of recharge to the system. Mathematical simulation of the ground-water flow system by Williamson and others (1989) indicates that the hydraulic-head distribution in the confined zone beneath the Corcoran Clay Member of the Tulare Formation was quite similar to the hydraulic-head distribution in the upper semiconfined zone. Their numerical simulation model indicates that hydraulic head in the lower confined zone was typically 10 to 20 feet lower than the hydraulic head in the upper semiconfined zone along the Coast Ranges and 0 to 10 feet higher along the valley trough.

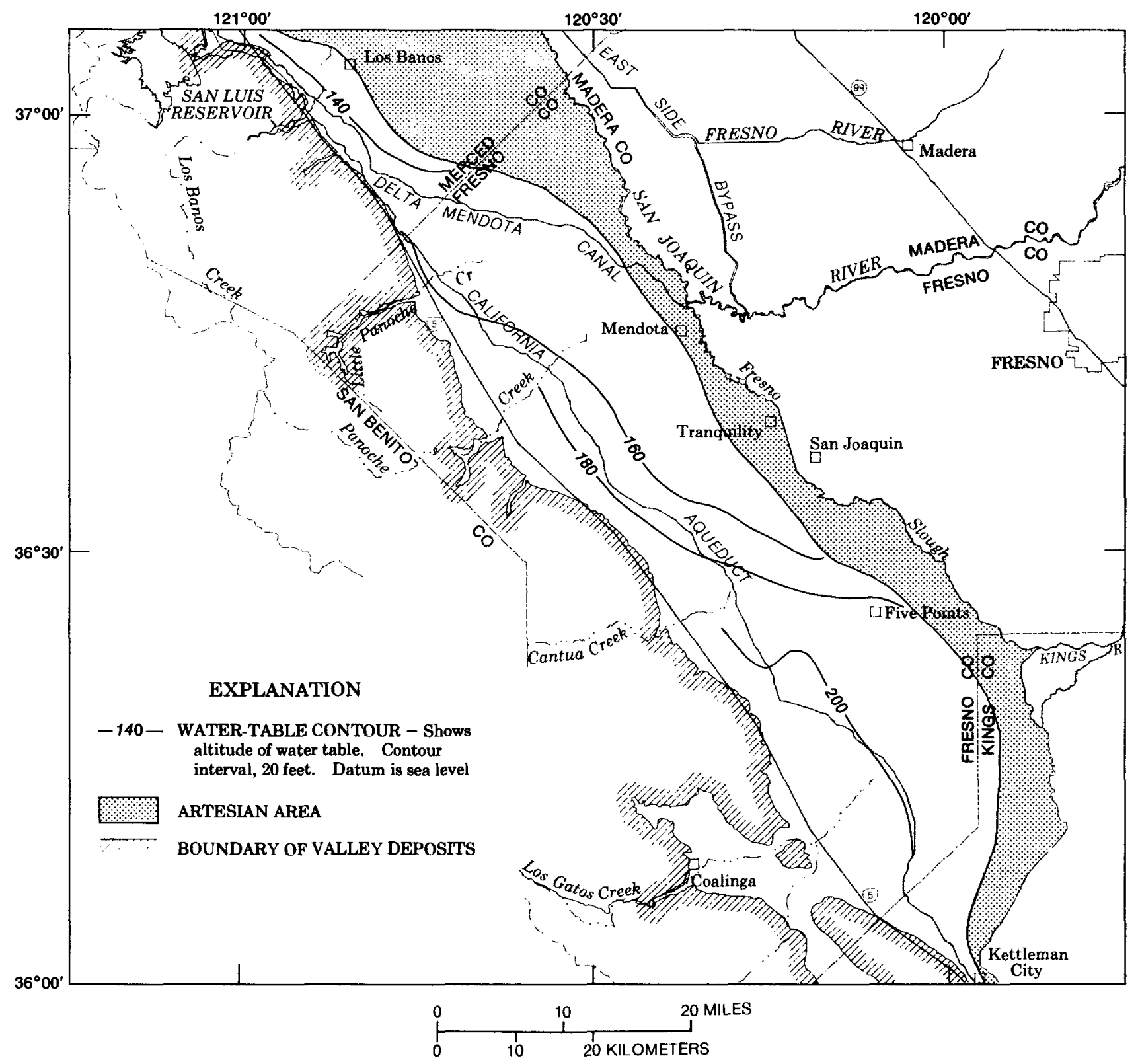

Figure 9. Estimated water-table altitude and extent of artesian areas, 1908. (Modified from Mendenhall and others, 1916.) 


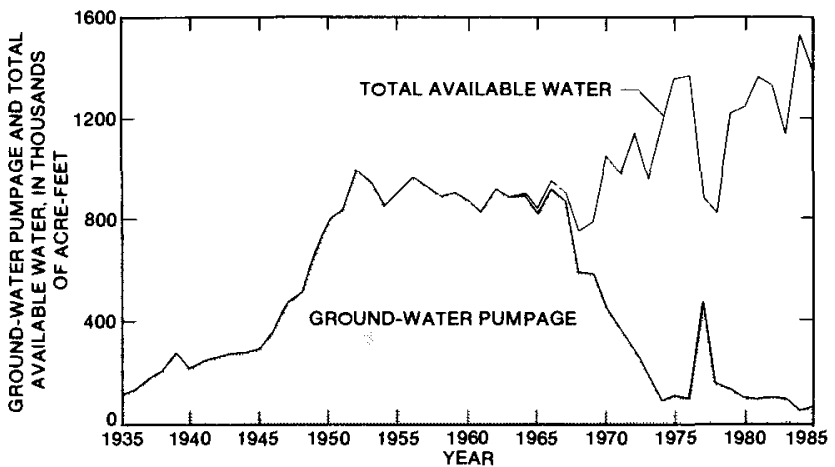

Figure 10. Ground-water pumpage and total available water, Westlands Water District, 1935-85 (Westlands Water District, written commun., 1985).

\section{Agricultural Development and System Response}

Agricultural activity in the study area began as early as the 1870 's, but large-scale farming and irrigation did not occur until the First World War (Davis and Poland, 1957; Bull and Miller, 1975). Irrigation with ground water expanded rapidly in the 1920's and steadily increased until World War II. After World War II, the price of commodities stimulated increased agricultural growth (Davis and Poland, 1957), and by the early 1950's nearly 1 million acre-feet of water was being pumped from the aquifer system within Westlands Water District, the largest water district in the study area (fig. 10). Most of the water was pumped from beneath the Corcoran Clay Member of the Tulare Formation. The increase in irrigated acreage (fig. 11 ) and in pumpage significantly altered the ground-water

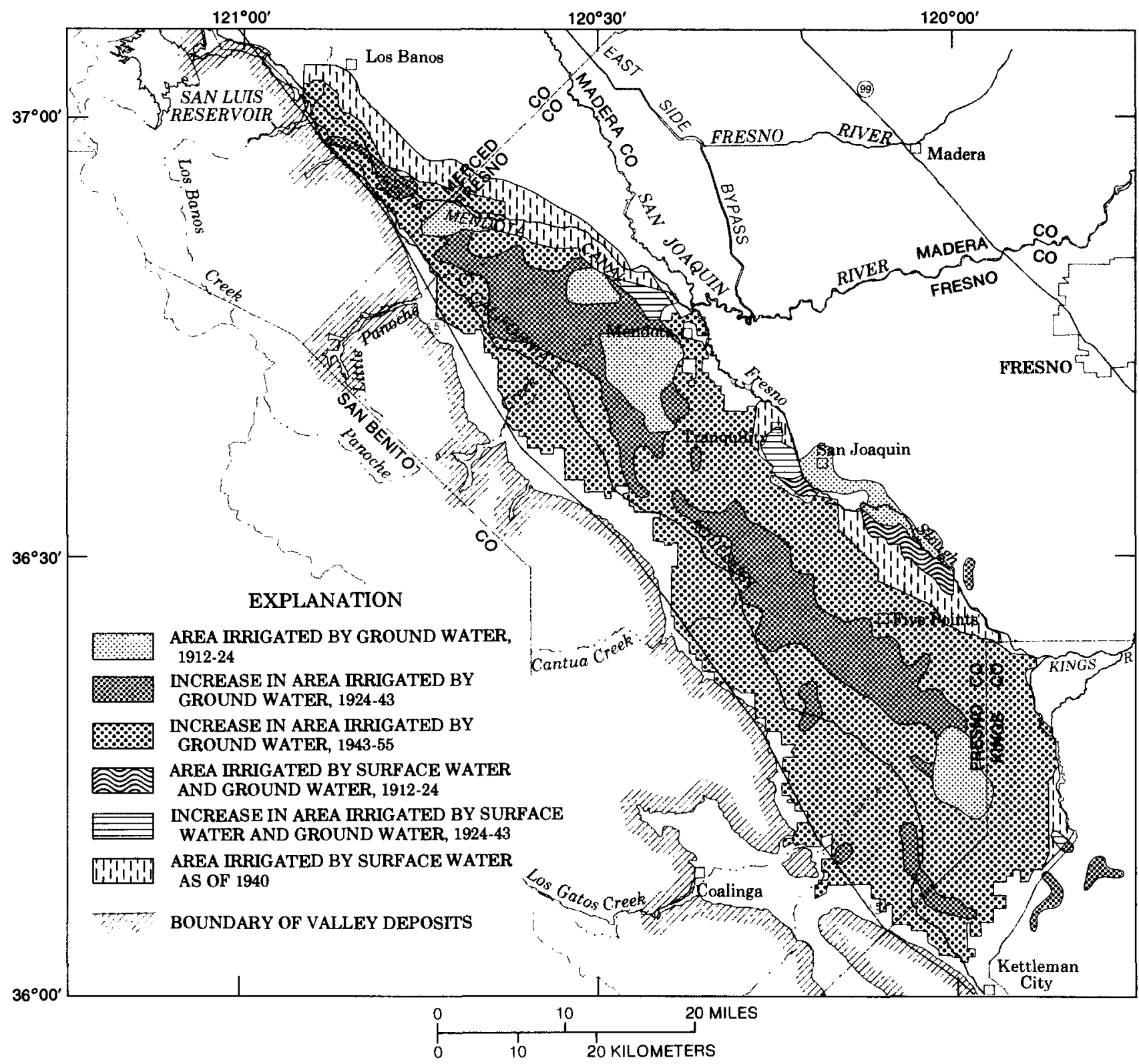

Figure 11. Extent of areas irrigated with ground water and surface water, 1912-55. (Modified from Bull and Miller, 1975.) 
flow system. Percolation of irrigation water past crop roots greatly exceeded infiltration of intermittent stream water and replaced the latter as the primary mechanism of recharge. Discharge of water through wells and evapotranspiration from crops replaced natural evapotranspiration as the primary mechanism of discharge. Williamson and others (1989) concluded that overall postdevelopment recharge during 1961-77 was more than 40 times greater than the estimated predevelopment values for the Central Valley.

Pumping of ground water in the central part of the western valley affected the hydraulic head and the direction of flow in the system. The most pronounced changes occurred in the lower confined zone. By 1952, the potentiometric surface of the confined zone (fig. 12) was drawn down 100 to 200 feet from the presumed predevelopment altitude. The large drawdown in hydraulic head created a reversal in the direction of flow in the lower confined zone from eastward to westward and also caused a significant component of vertical flow from the overlying semiconfined zone.

The changes in the altitude of the water table were less marked than the changes in hydraulic head in the confined zone during the early period of intensive develop-

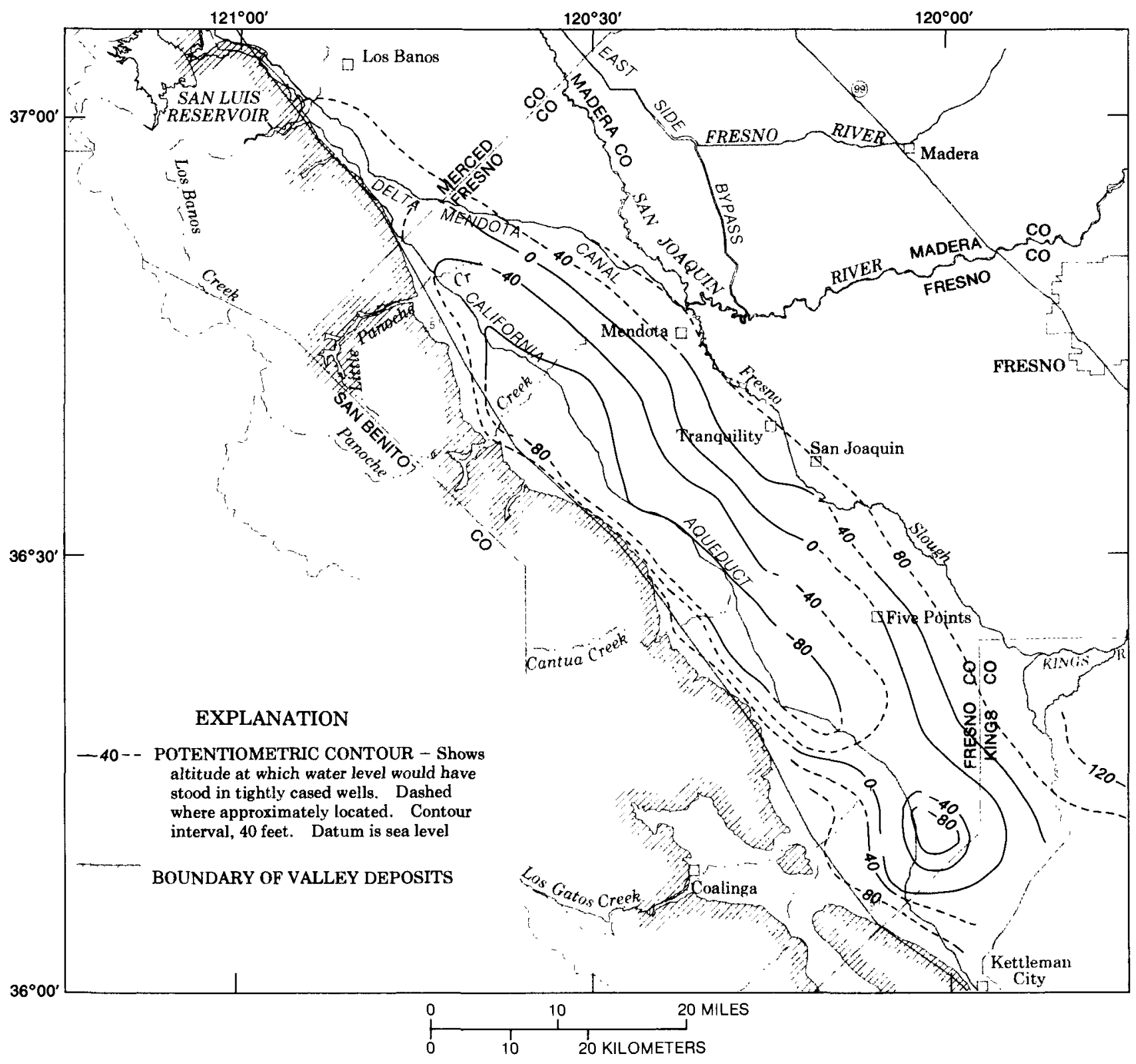

Figure 12. Potentiometric surface of confined zone, 1952. (Modified from Davis and others, 1959.) 
ment. Comparison of maps of the altitude of the water table in 1908 (fig. 9; Mendenhall and others, 1916) and in 1952 (fig. 13; Davis and others, 1959) indicates a lowering of the water table along the distal-fan margins and the valley trough. Water-table declines in these areas were probably the result of pumping from the Sierran sand. In contrast to these water-table declines, the altitude of the water table was apparently unchanged to slightly elevated (Davis and
Poland, 1957) along the western part of the area from 1906 to 1952 , except for the development of an oblate mound southeast of the Panoche Creek. It is possible, however, that this mound was not actually present. Davis and others' (1959) map probably was not corrected for land subsidence, which was already substantial by the time their map was prepared and was greatest in the area of the apparent mound.

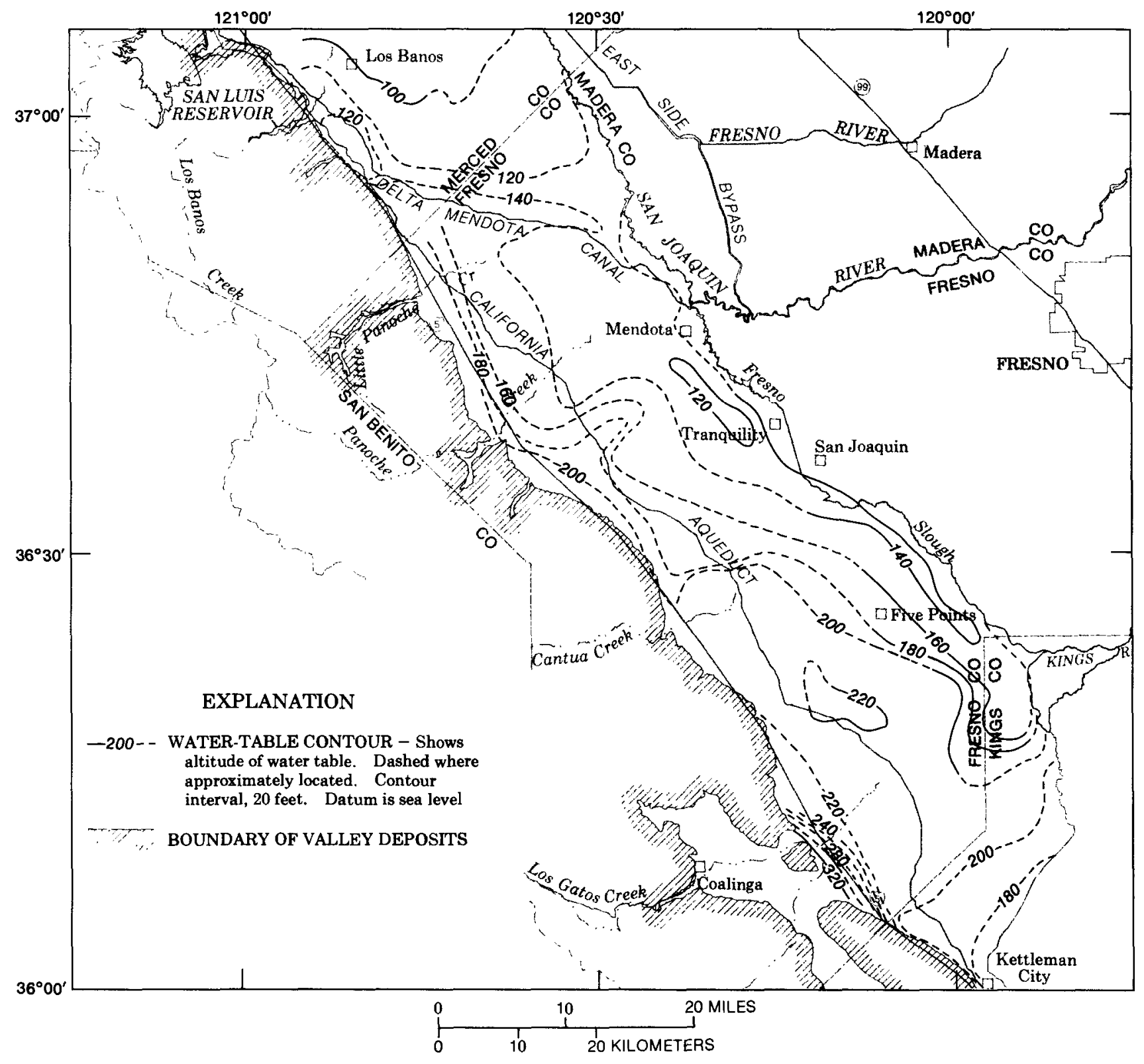

Figure 13. Water-table altitude, spring 1952. (Modified from Davis and others, 1959.) 
Agricultural pumpage in excess of recharge continued for more than a decade after 1952 and led to further lowering of the potentiometric surface of the confined zone. By 1967, the potentiometric surface (fig. 14) had been lowered hundreds of feet over much of the western valley. The large quantities of ground water pumped from the aquifer system had several significant effects, including steepening of westward gradients in the confined zone. substantial increase in pumping lifts, and land subsidence (fig. 15). Pumping lifts exceeded 800 feet over parts of the area, and land subsidence of more than 2 feet occurred throughout the study area, with local subsidence reaching as much as 28 feet by 1972 .

As a result of land subsidence, increased pumping lifts, and water quality limitations, surface water was imported to the western valley in order to decrease pumpage

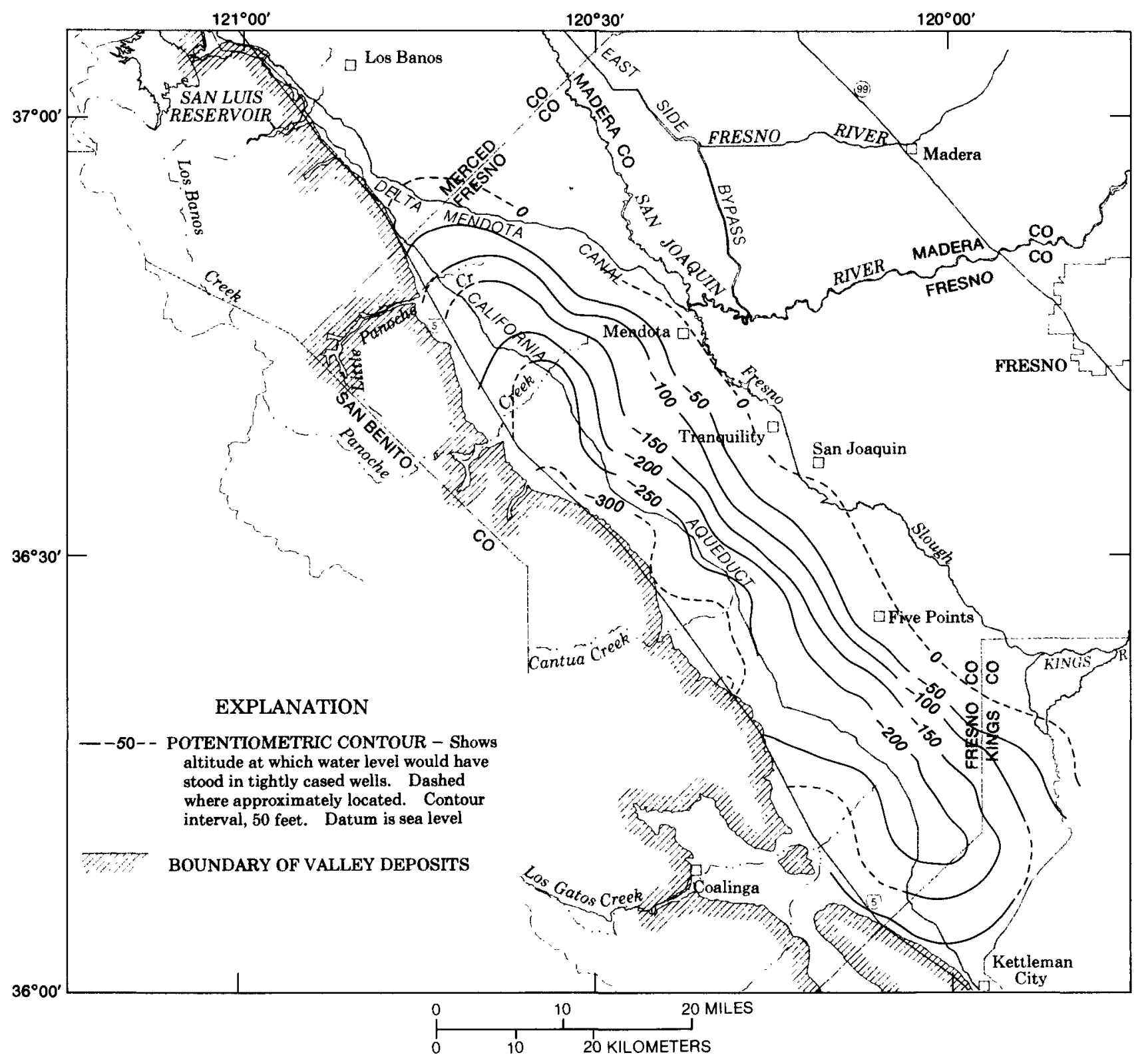

Figure 14. Potentiometric surface of confined zone, December 1967. (Modified from Ireland and others, 1984.) 
from the aquifer system. Beginning in 1967, surface water imported via the California Aqueduct began to replace ground water as the primary source of irrigation supply in the area south of Mendota. The availability of surface water led to an increase in the total quantity of water applied, whereas the quantity of water removed from the system by wells decreased (fig. 10). The marked decrease in pumpage has allowed a recovery in hydraulic head throughout the aquifer system. Comparison of the maps of the potentiometric surface of the confined zone in 1967 and 1984 (figs. 14 and 16) indicates that hydraulic head in the confined zone rose 200 to 300 feet from 1967 to 1984 along the western part of the study area in areas previously characterized by the largest drawdown. Hydraulic head in the valley trough typically rose 100 feet. Overall, the rise in the potentiometric surface from 1967 to 1984 was nearly

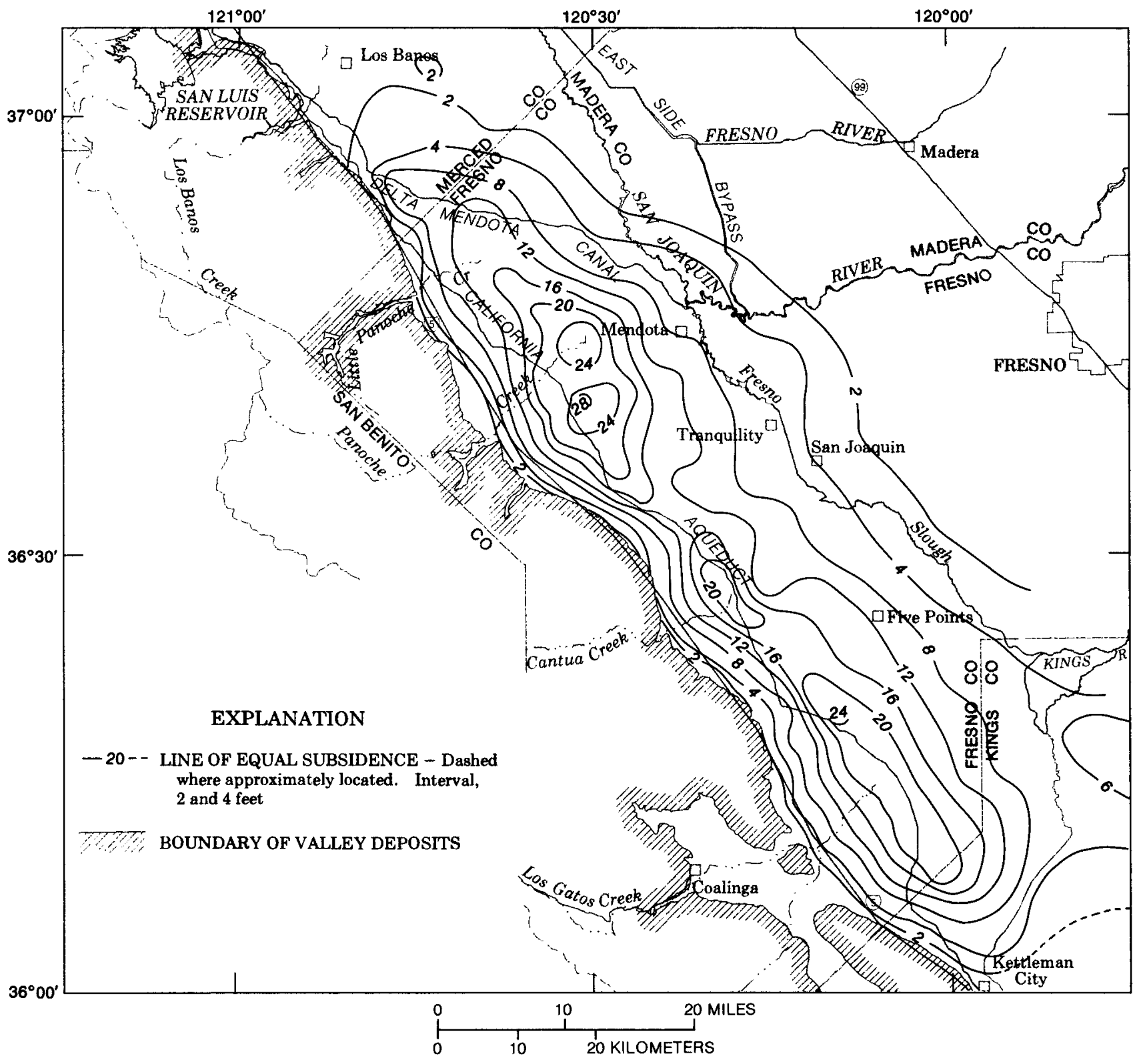

Figure 15. Land subsidence, 1926-72. (Modified from Ireland and others, 1984.) 
one-half the drawdown that occurred from predevelopment conditions to 1967 .

Agricultural development also has affected the semiconfined zone, which overlies the Corcoran Clay Member. Increased rates of recharge resulting from percolation of irrigation water (as compared to predevelopment recharge rates), combined with the rapid post-1967 decrease in pumpage, caused a rise in the altitude of the water table over much of the western valley. Comparison of maps of the depth to the water table in 1952 (fig. 17) and 1984 (fig. 18 ) indicates this marked change in the system (wells used to map water-table depth and altitude are shown in figure 19). In 1984, about one-half of the study area was characterized by a water table within 20 feet of the land surface, whereas in 1952 only a small percentage of the western valley was underlain by shallow ground water. Indeed,

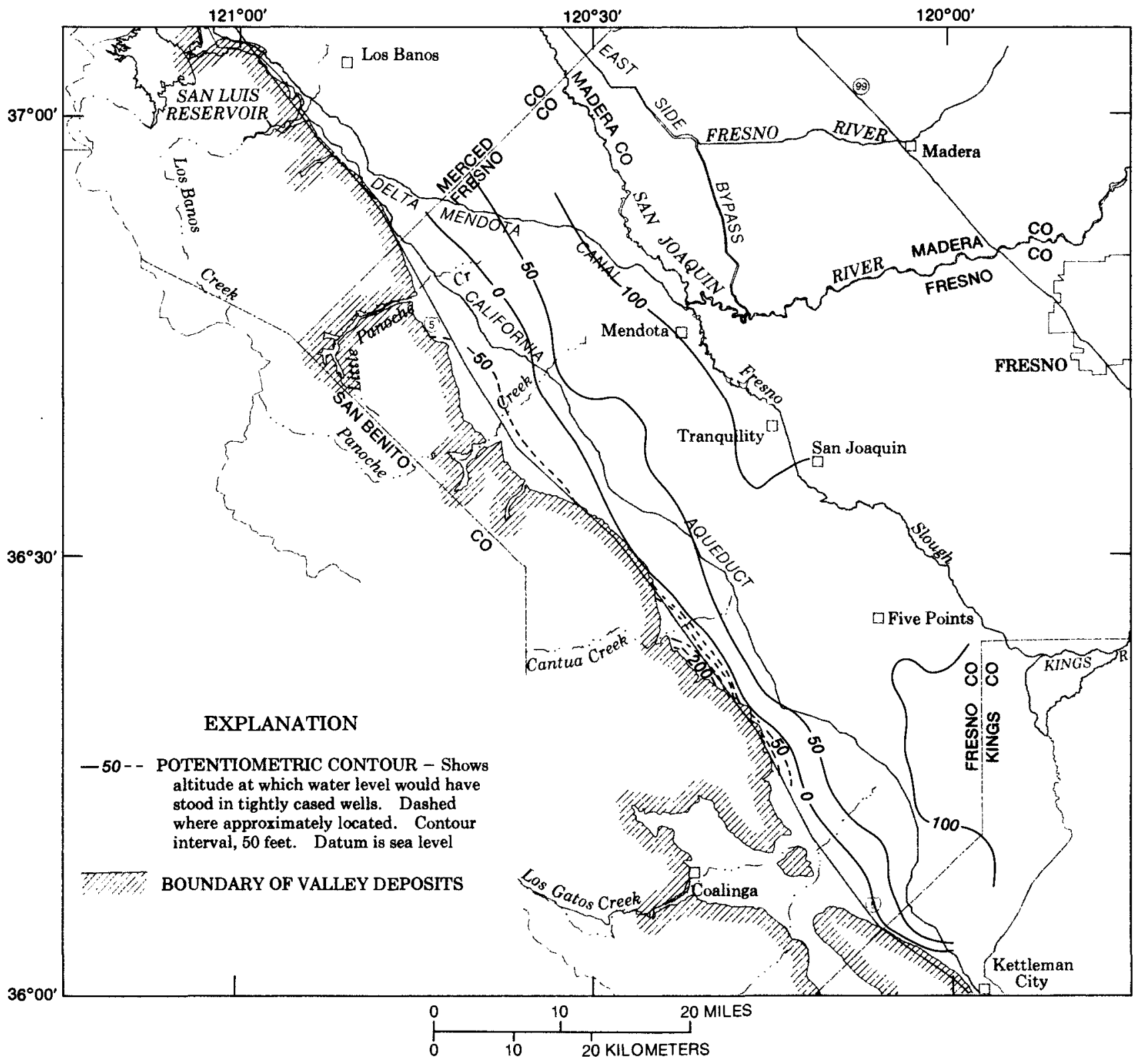

Figure 16. Potentiometric surface of confined zone, spring 1984. 
much of the area underlain by a water table within 20 feet of the land surface in 1984 was characterized by a water table at depths of 100 to 200 feet in 1952. The development and growth of areas with a shallow water table and resulting drainage problems have long been a key concern of agricultural interests in the area.

Wells completed in the deepest parts of the semiconfined zone indicate that the rise in hydraulic head has been larger in the deeper parts of the semiconfined zone than in the shallower parts. Hydrographs for two wells near the California Aqueduct, both at a land-surface altitude of 320 feet but drilled to different depths ( 48 and 184 feet), show increases in water level of about 20 feet in the shallower well and 40 feet in the deeper well from 1975 to 1984 (fig. 20). Moreover, the hydraulic-head rise in the confined zone was about 100 feet at that location during the same time

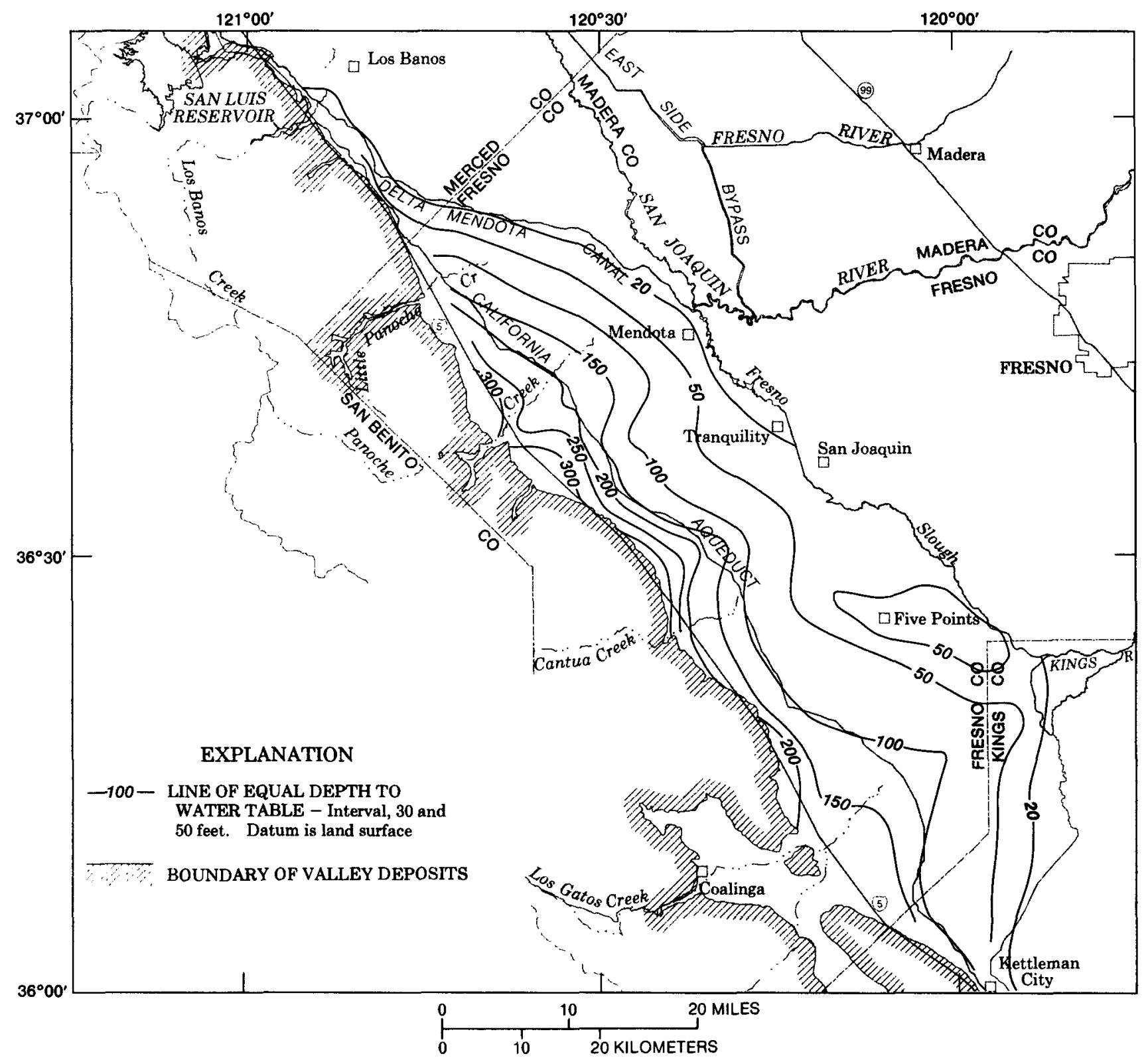

Figure 17. Depth to water table, spring 1952. (Modified from Davis and others, 1959.) 
period. These observations indicate a decrease in the downward head gradient over time. The decrease can be attributed to the decrease in pumpage from beneath the Corcoran Clay Member.

In contrast to most of the study area, comparison of the depth to the water table in 1952 (fig. 17) and 1984 (fig. 18) in the western parts of the alluvial fans indicates that the water-table altitude declined along most of the western part of the alluvial fans. In 1952, the water table was generally within 200 feet of the land surface in the western parts of the alluvial fans, whereas, in 1984, the water table was typically more than 300 feet beneath the land surface in those areas. The increase in depth to the water table was especially pronounced beneath the fanhead of the Los Gatos Creek alluvial fan, where in 1952 the water table was within 200 feet of the land surface over most of the fanhead. In

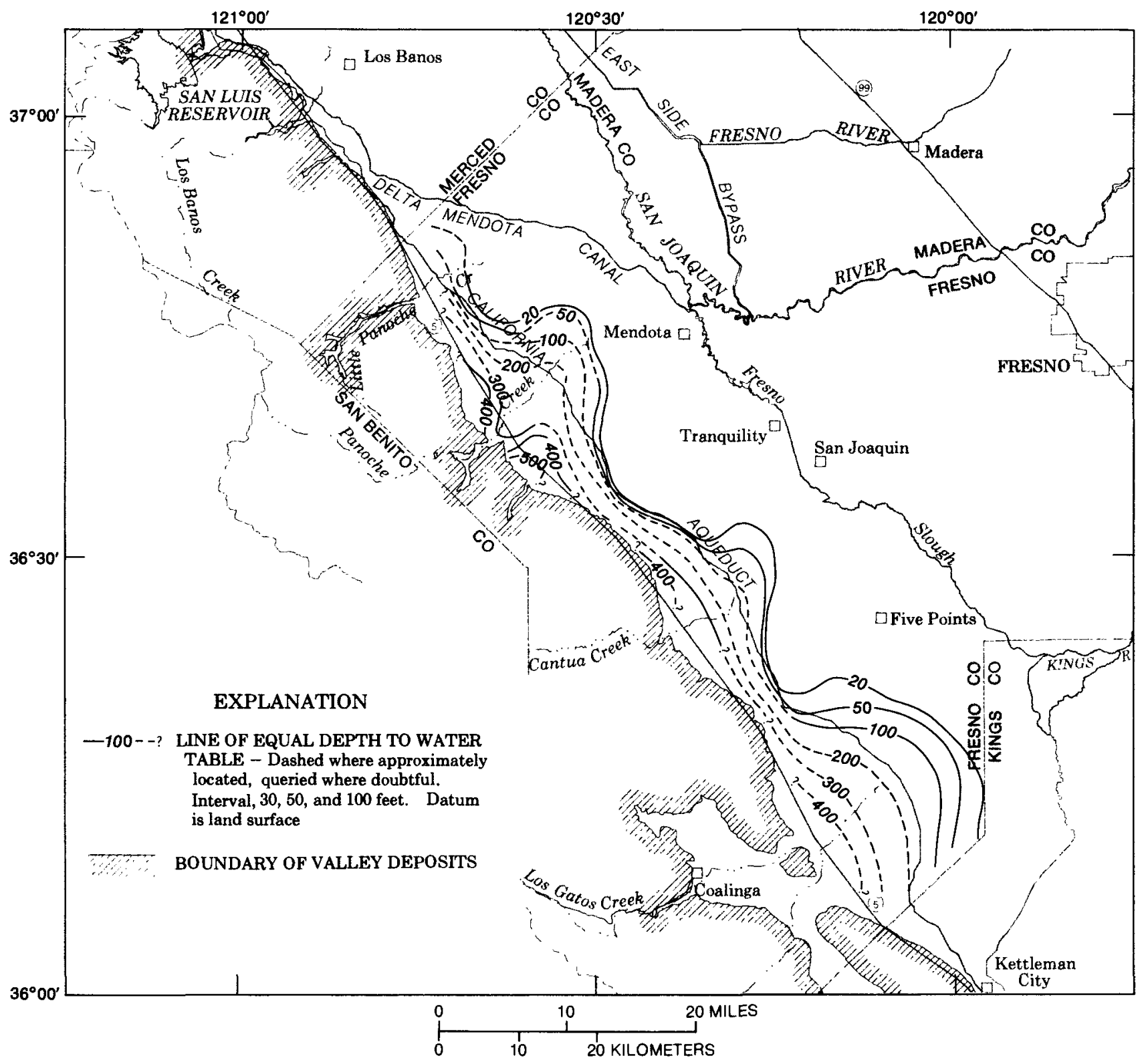

Figure 18. Depth to water table, October 1984. Wells used to map depth to water table are shown in figure 19. 
contrast, the depth to the water table in 1984 was more than 400 feet over parts of the fanhead of the Los Gatos Creek alluvial fan. It is important to note that the map of the depth to the water table in 1952 is an approximation constructed, in part, using electrical-resistivity logs (Davis and others, 1959). Therefore, the numerical values of water-table decline used in this study also need to be considered approximate.
The overall decline of the water table from 1952 to 1984 was probably a result of the large overdraft from the confined zone that occurred prior to the importation of surface water. The areas of water-table decline along the western part of the alluvial fans correlate with the areas of greatest drawdown in the confined zone. Indeed, the watertable decline was most areally extensive within the fanhead of the Los Gatos Creek fan, where the Corcoran Clay

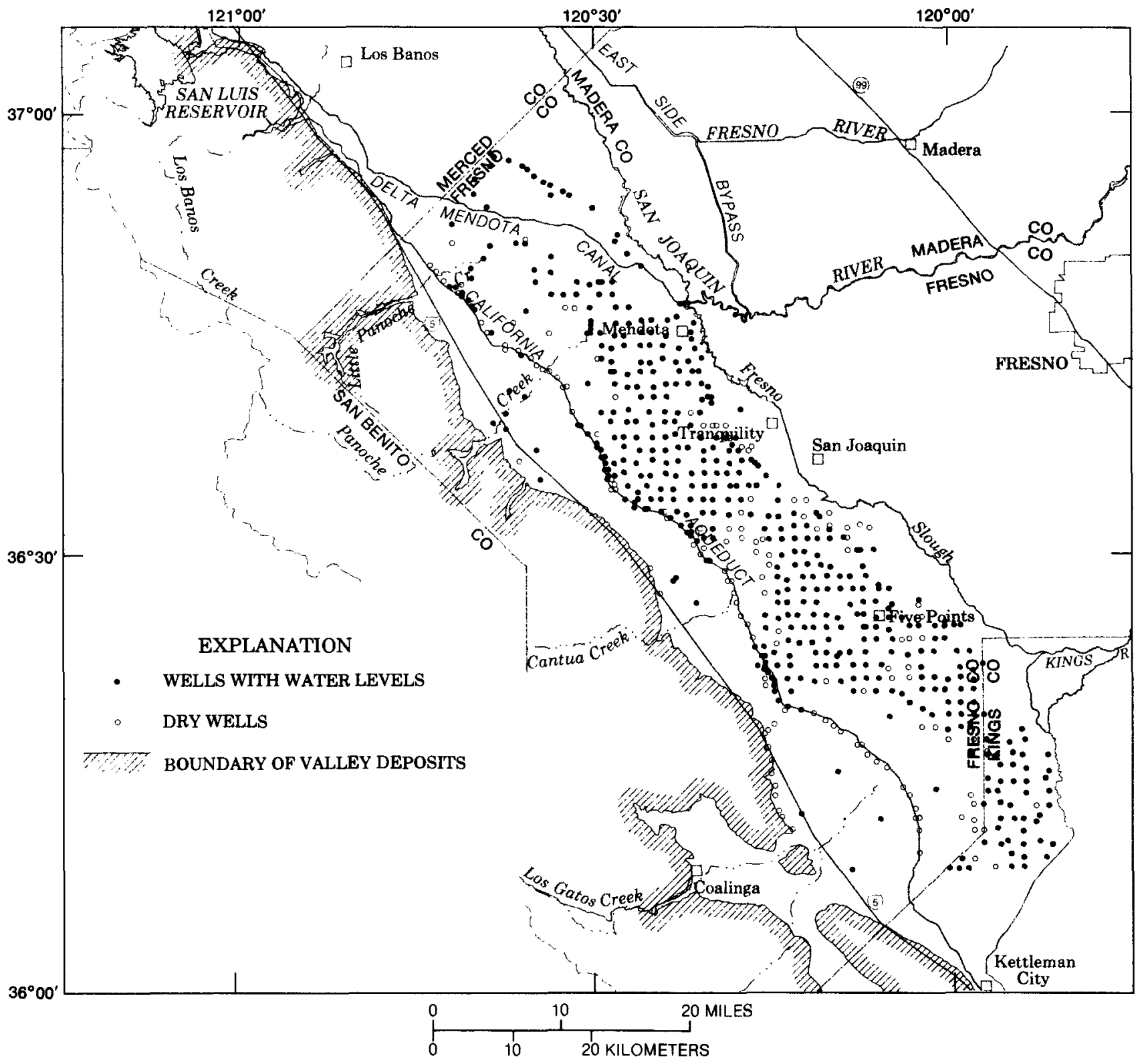

Figure 19. Wells used to map depth to and altitude of water table, October 1984. 
Member is absent over a large area (figs. 5, 18); the absence of the Corcoran allows for an enhanced hydraulic connection between the semiconfined and confined zones. Inspection of hydrographs in the areas of water-table decline indicates that water levels in wells completed in the semiconfined zone have been rising since 1967. The overall decline of the water table from 1952 to 1984 in the western parts of the alluvial fans indicates that although the water table rose in those areas after 1967, by 1984 the system had not yet recovered to the 1952 levels.

A regional tile-drain collector system, which was installed during 1980-81, also has had significant effects on the ground-water flow system. This system underlies about 42,000 acres (65.6 square miles) of land west and southwest of Mendota (fig. 21). During 1981-84, the drains collected an average of 6,900 acre-feet per year $(0.16$ cubic foot per year per square foot). By diverting water that might have otherwise recharged the ground-water flow system, the drains lowered water levels in the drained area 1 to 3 feet on a regional scale and as much as 5 feet on a local scale. In addition, the drains have decreased seasonal variation in water levels in the drained area.

By lowering water levels 1 to 3 feet in the drained area, the tile-drain collector system was effective in decreasing the total area characterized by a water table within 5 feet of the land surface. Maps of depth to the water table (Westlands Water District, written commun., 1986)

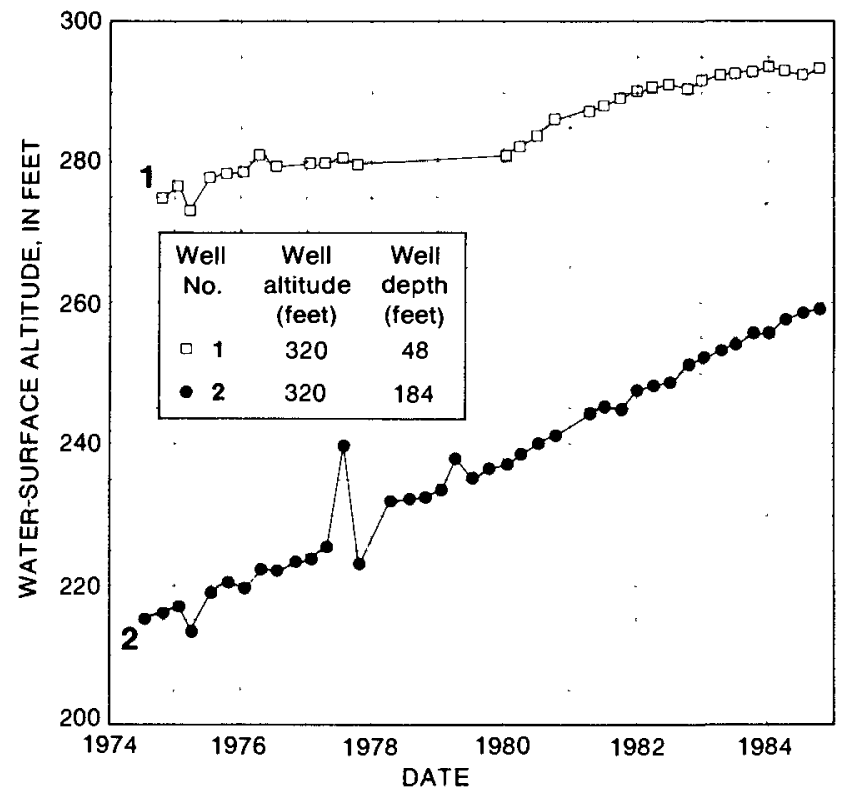

Figure 20. Hydrographs of two wells drilled to different depths in semiconfined zone. Well locations are shown in figure 21. indicate that in April 1976 about 27 square miles or 41 percent of the area later serviced by drains had a water table within 5 feet of the land surface. By April 1984, the size of this area had decreased to 4 square miles or 6 percent of the drained area. In contrast, in an area of equivalent size, topographic relief, and geomorphic character, but not underlain by regional tile drains (fig. 21), the size of the area underlain by a water table within 5 feet of the land surface increased from 8 square miles in April 1976 to 18 square miles in April 1984.

Hydrographs of eight wells along a west-to-east line, through an area where the Panoche Creek and Cantua Creek alluvial fans coalesce (fig. 21), are shown in figure 22. The west-to-east line is nearly perpendicular to the contours of the altitude of the water table and thus nearly corresponds to the lateral component of ground-water flow. The hydrographs illustrate the effects of the drains on the groundwater flow system, and they also show the local-scale variability of the ground-water flow system. In general, shallow wells in the drained area (more than 50) have shown smaller seasonal variation in water levels since the drains were installed than before their installation and also have shown smaller seasonal variation than several hundred shallow wells in the undrained area. In addition, water levels in the drained area have been steady since the drains were installed, whereas wells in the undrained areas commonly have shown a rise in water levels. Wells 7,8 , and 9 (fig. 22) in the drained area have had relatively constant water levels with reduced seasonal variation since 1981 . Although wells 5 and 6 are within the drained area, their water levels were apparently unaffected by the installation of the drains. Wells 1, 3, and 4 are in areas not underlain by drains and have shown rising water levels over time; they also have shown seasonal water level variation of 1 to 5 feet. Well 1 is close to the California Aqueduct and has not shown seasonal variation in water level for the period of record. Many wells have deviated from these general trends, as water level changes in the study area are quite variable.

\section{Configuration of Water Table in 1984}

The configuration of the altitude of the water table in 1984 is shown in figure 23 . The water table demarcates the top of the zone of saturation. In many investigations, flow is assumed to be horizontal and equipotential lines vertical. If these assumptions were true, then the spatial distribution of the altitude of the water table could be taken as representative of the areal distribution of hydraulic head for the aquifer. However, vertical flow is substantial in the western San Joaquin Valley, and thus the altitude of the water table is not representative of the hydraulic head at 
other depths. Nonetheless, the map showing altitude of the water table can be used to determine the general direction of the lateral component of flow in the semiconfined zone.

One of the most notable features of the 1984 water table is the ground-water divide that more or less parallels the west boundary of the alluvial fans (fig. 23). This divide shifts westward between the fanheads of the major alluvial fans and shifts eastward near the fanheads. To the east of the ground-water divide, the water table lies at shallow depths and is a subdued replica of the topography. East of the divide, ground-water flow is eastward and northeastward, reflecting the general trend of the topography. In part of the study area, there is a component of flow eastward across the valley trough toward pumping wells perforated in the Sierran sand. To the west of the ground-water divide, the water table slopes steeply to the west, opposite in

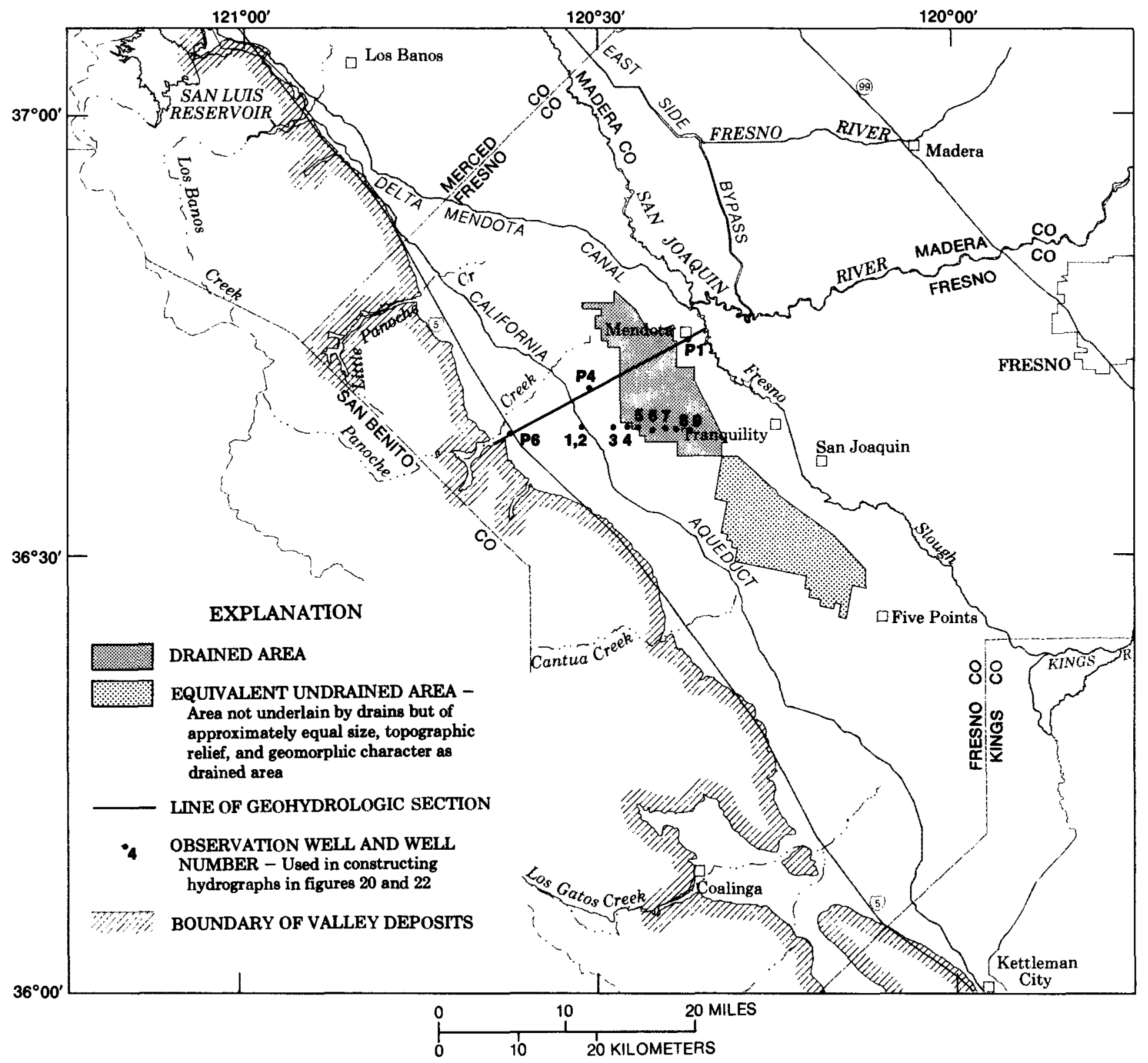

Figure 21. Location of area serviced by regional tile-drain system and area of approximately equivalent size, topographic relief, and geomorphic character. Geohydrologic section is shown in figure 24. 
direction to the land surface. West of the divide, flow is toward the Coast Ranges and the fanhead areas.

The existence and location of the ground-water divide are related to historical agricultural activity in the area and to the texture of the subsurface deposits. Comparison of the 1984 altitude of the water table (fig. 23) with the altitude in 1952 (fig. 13) indicates a lowering of the water table over at least part of the area to the west of the divide and a rise in the water table over much of the area to the east of the divide. The area of the lowered water table in the western parts of the alluvial fans corresponds to the area of maximum drawdown in hydraulic head in the confined zone: both can be related to historical pumping, which occurred primarily from the confined zone. The rise in the water table to the east of the divide is probably related to increased rates of recharge to the system due to percolation of irrigation water past crop roots.

The location of the ground-water divide is partly affected by the texture of the subsurface sediments. The ground-water divide shifts eastward in the fanhead areas, where the sediments are coarsest grained, and shifts westward in the interfan areas, where the sediments are finest grained. The altitude of the water table is the lowest, and the ground-water divide farthest to the east, beneath the

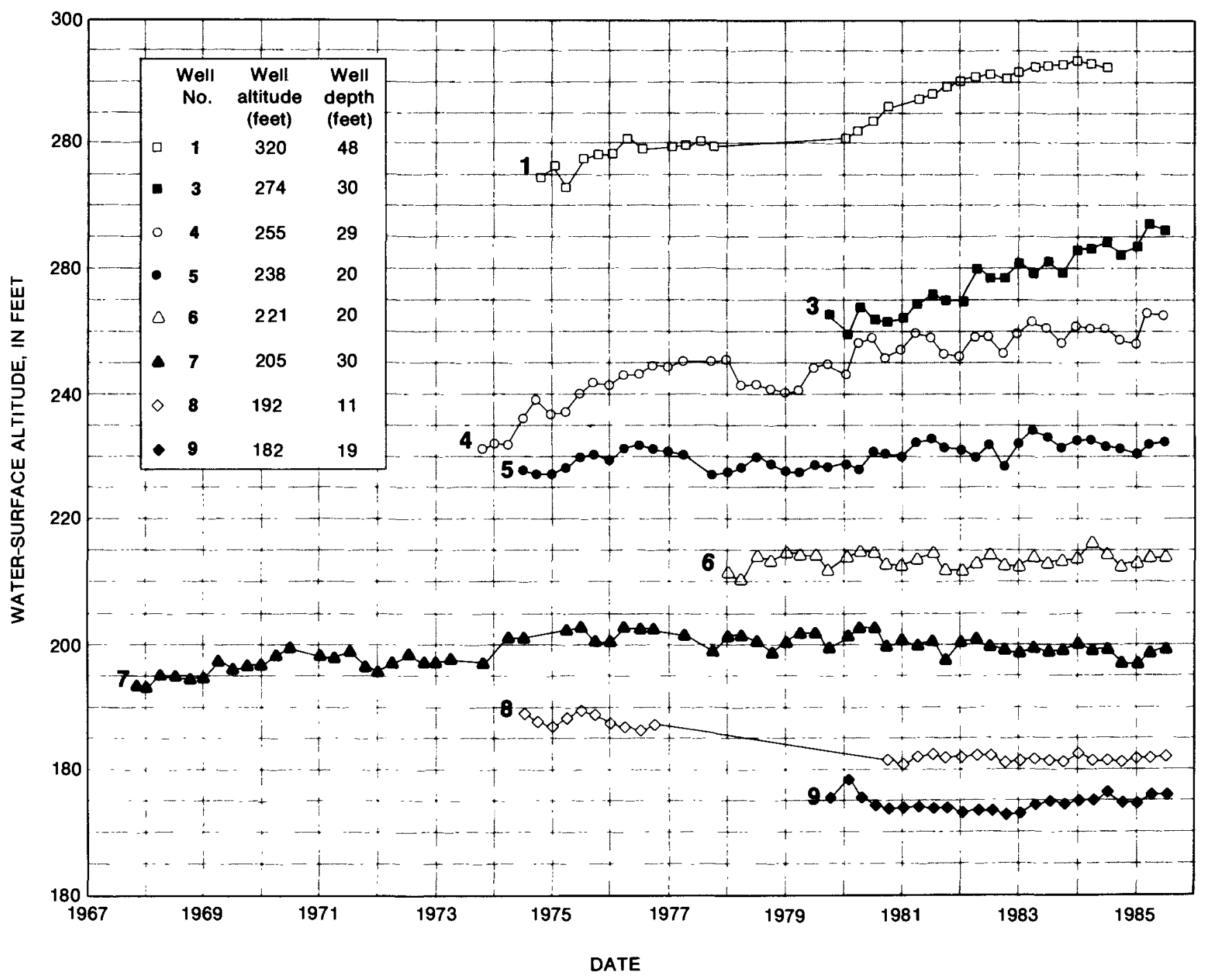

Figure 22. Hydrographs of eight wells along approximate flow line. Well locations are shown in figure 21. 
fanhead of the Los Gatos Creek alluvial fan. This area corresponds to the area where the Corcoran Clay Member of the Tulare Formation is not present. The absence of the Corcoran results in better hydraulic connection between the semiconfined and confined zones.

Because texture affects the specific yield and the permeability of the deposits, texture affects system response to hydraulic stresses. The dominant boundary conditions for the semiconfined zone are the downward percolation of irrigation water past crop roots and the hydraulic head of the confined zone. The hydraulic head is in turn affected by pumping. The percolation of irrigation water past crop roots has resulted in accretion to the water table over a large area. Because fine-grained deposits tend to have smaller specific yield than coarse-grained deposits, the water-table accretion tends to be greatest in areas of fine-grained deposits, such as

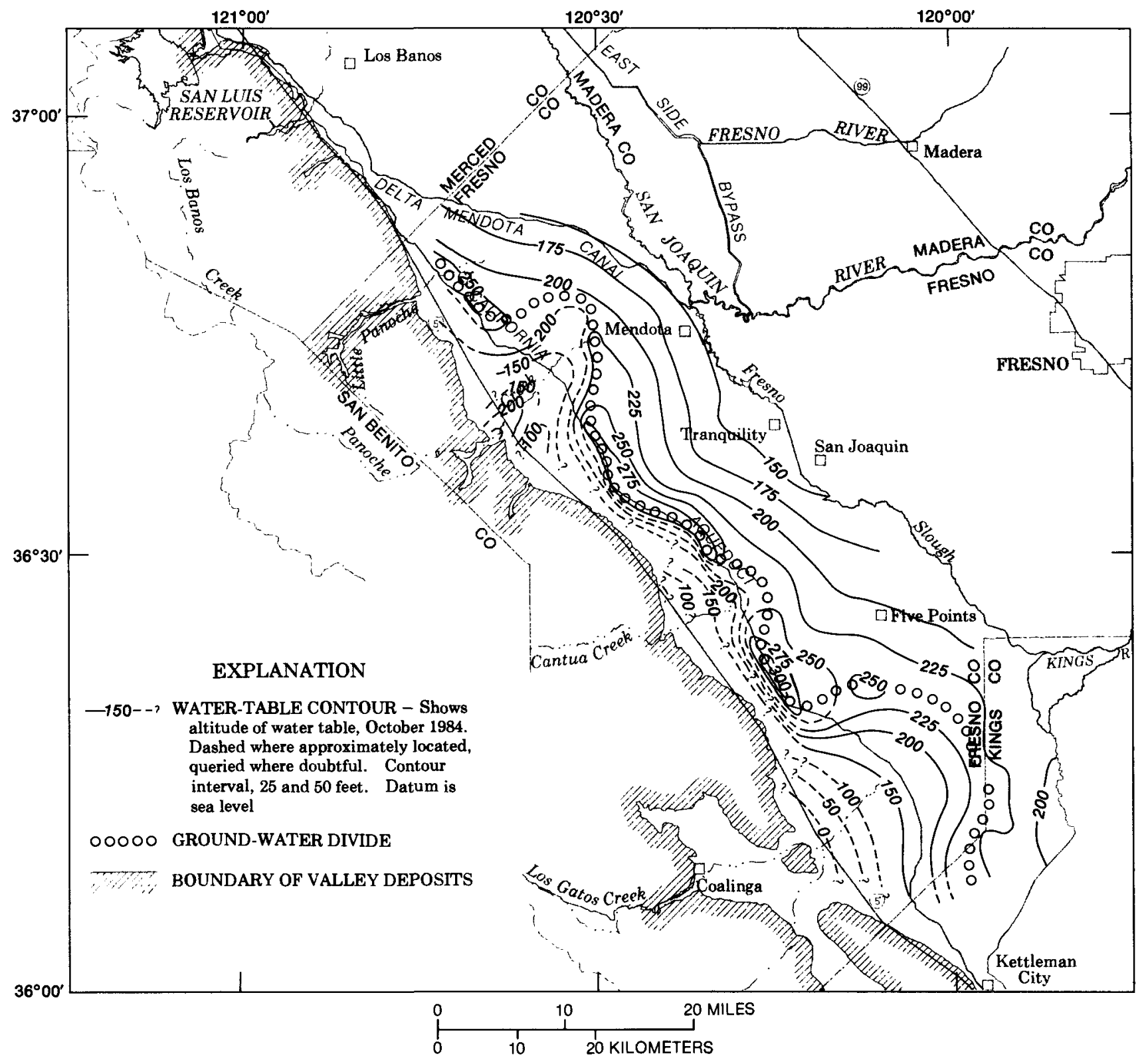

Figure 23. Water-table altitude, October 1984. Wells used to map water table are shown in figure 19. 
interfan areas. The combined effect of pumping from below the Corcoran and percolation from above the water table has been development of a large downward flow gradient in the semiconfined zone. Because the fine-grained sediments tend to have lower permeability than the coarse-grained sediments, a larger vertical head gradient is required to transmit a given quantity of water through the fine-grained deposits than through the coarse-grained deposits. Consequently, the interfan areas have larger vertical head gradients than occur in the fanhead areas. The larger vertical head gradient translates to a thicker saturated column and hence shallower depth to ground water than in the fanhead areas.

\section{Vertical Gradients}

Under natural (predevelopment) conditions, the ground-water flow system of the western San Joaquin Valley was characterized by horizontal flow over most of the area. Numerical simulation of the flow system by Williamson and others (1989) indicates that, historically, vertical gradients were small and limited to the fanhead areas (where there was a downward gradient) and to the valley trough (where there was an upward gradient). Presently, the flow system above the Corcoran Clay Member of the Tulare Formation is characterized by a large component of downward flow over most of the study area.

Vertical gradients of hydraulic head were calculated at 37 locations in the study area. At locations with two or more wells, the gradient was calculated by dividing the difference in water levels by the distance between the midpoints of the perforated intervals. At locations with a single deep well, gradients were calculated only at sites where shallow water levels could be interpolated to within 3 feet with a fair degree of confidence from the water-table map (fig. 23). Vertical gradients during 1984-86 ranged from 0.003 to 1.1 ; in contrast, horizontal head gradients in the western valley typically ranged from 0.001 to 0.02 .

Vertical gradients in hydraulic head are smaller in the coarse-textured Sierran sand and fanhead alluvium than in the finer textured midfan, distal-fan, and flood-basin deposits. The largest gradients occur beneath the California Aqueduct in areas of fine-grained deposits and in the flood-basin clays in areas where there is pumping-induced drawdown in the Sierran sand. Vertical gradients within the coarse-textured Sierran sand and fanhead alluvium ranged from 0.003 to 0.07 during 1984-86. During the same period, gradients in the midfan areas ranged from 0.07 to 0.32 except beneath the California Aqueduct, where gradients ranged from 0.08 to 1.0 . Gradients in the fine-textured flood-basin deposits ranged from 0.10 to 1.1 .
Gradients near one and equal to one beneath the aqueduct may indicate local perched-water conditions, in which saturated deposits overlie unsaturated deposits. The possible perching may be the result of preconstruction ponding along the canal right-of-way and of leakage from the canal. Gradients near one and greater than one in the valley trough near San Joaquin and Tranquility may indicate perching over a larger area. Pumping of ground water from the Sierran deposits has lowered the water levels in the Sierran sand to an altitude below that of the interface between the overlying flood-plain deposits and the Sierran sand, producing an unsaturated zone between the finegrained flood-plain deposits and the Sierran sand. The low diffusivity of the clays in the flood-plain deposits has allowed these deposits to remain saturated as the water table in the semiconfined zone declined below the interface.

Pumpage from the Sierran sand was greater in the past than it is now. The present-day extent of the perched zone probably is smaller than it was in the past, and the area of perched-water conditions will continue to decrease with decreasing pumpage.

\section{Generalized Geohydrologic Section Through Flow System}

A generalized geohydrologic section through the flow system is shown in figure 24 . The cross section extends from the fanhead of the Panoche Creek alluvial fan to Mendota (fig. 21). The section shows the generalized geology and the distribution of hydraulic head. The geology of the section was interpreted from published maps and sections (Page, 1986; U.S. Bureau of Reclamation, 1965). Records of direct observations of hydraulic head are available from several sources. Observations of the vertical distribution of head in the semiconfined zone and across the Corcoran Clay Member of the Tulare Formation are available from multiple wells drilled to various depths by the U.S. Geological Survey at three sites: P6, P4, and P1 (fig. 21 ). The altitude of the water table is well documented in areas where the water table is within 20 feet of the land surface because the Westlands Water District maintains a network of shallow wells to monitor the water table in those areas. The distribution of hydraulic head beneath the Corcoran Clay Member is known from maps of the potentiometric surface of the confined zone prepared by the Westlands Water District and by the California Department of Water Resources, and from the wells drilled by the U.S. Geological Survey.

The distribution of hydraulic head within the semiconfined zone in regions without wells was inferred by interpolation between wells and based on the known hydro- 
geology of the system. In particular, the orientation of the equipotential lines in the area between the P6 and P4 wellsites was drawn to reflect the distribution of electrical resistivity as mapped by Robert Bisdorf of the U.S. Geological Survey (written commun., 1986). The equipotential lines were contoured more vertically where the resistivity indicates coarse-grained deposits and were contoured more horizontally where the resistivity indicates fine-grained deposits. The inferred distribution of hydraulic head in the Corcoran Clay Member is based on the known and interpreted values of hydraulic head above and below the clay.

The section as drawn (fig. 24) shows a nearly vertical equipotential line in the Sierran sand. Time-series data for the wells at the Mendota Airport indicate that the vertical gradient varies seasonally at that site. During the late autumn and winter, the vertical head gradient is as low as 0.003 , and in the late spring and summer, the head gradient is as high as 0.07 . The increased vertical head gradient during the late spring and summer is probably attributable to nearby pumping.

Arrows are drawn on the section to indicate the general directions of ground-water flow. The arrows illustrate several major aspects of the flow system. Ground water east of the ground-water divide flows downward toward the confined zone and eastward toward pumping wells located in and east of the valley trough. The orienta- tion of the arrows east of the ground-water divide reflects the contrast in hydraulic properties between the Coast Ranges alluvium and the Sierran sand. The more vertically oriented ground-water flow in the Coast Ranges alluvium is refracted toward the horizontal upon entering the Sierran sand. Ground water west of the ground-water divide flows toward a trough in the water table and downward toward the confined zone. The eastward-pointing arrow near the P6 wellsite (in the fanhead of the Panoche Creek fan) reflects the effects of the ground-water mound beneath Panoche Creek (fig. 23). The arrows also indicate downward flow across the Corcoran Clay Member from the semiconfined zone to the confined zone.

\section{CONCLUSIONS}

The Pleistocene Corcoran Clay Member of the Tulare Formation divides the ground-water flow system of the central part of western San Joaquin Valley into an upper semiconfined zone and a lower confined zone. The deposits of the semiconfined zone can be divided into three hydrogeologic units: Coast Ranges alluvium, Sierran sand, and flood-basin deposits. The texture of the Coast Ranges alluvium varies as a function of position on the alluvial fans. The deposits are coarse textured at the heads of fans

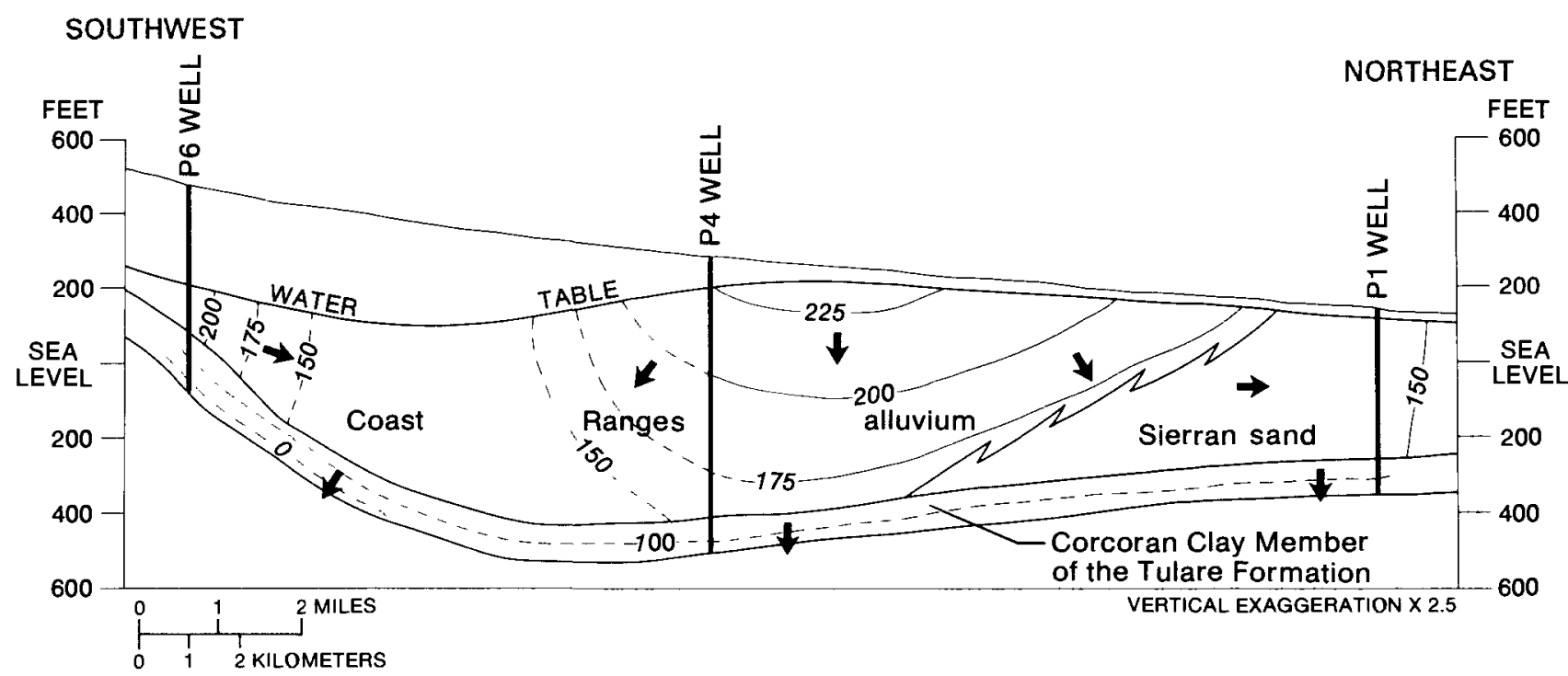

EXPLANATION

- 200- - - POTENTIOMETRIC CONTOUR - Shows altitude at which water level would have stood in tightly cased wells. Dashed where approximately located. Contour interval: above Corcoran, 25 feet; within Corcoran, 100 feet. Datum is sea level

\section{- GENERAL DIRECTION OF GROUND-WATER FLOW}

Figure 24. Generalized geohydrologic section through flow system. Location of section is shown in figure 21. 
and along present-day stream channels and paleochannels. The deposits are fine textured between channels and at the distal-fan margins. The Coast Ranges alluvial sediments were deposited under arid conditions and are generally oxidized. The Sierran sand, in the valley trough, consists of coarse-textured reduced deposits. The flood-basin deposits are predominantly fine-textured, moderately to densely compacted clays of variable oxidation state.

Agricultural development has significantly altered the ground-water flow system in the central part of the western San Joaquin Valley. Percolation of irrigation water past crop roots greatly exceeds and has replaced infiltration of intermittent streamflow as the primary mechanism of recharge. Pumpage of ground water from wells and crop evapotranspiration have replaced natural evapotranspiration and seepage to streams in the valley trough as the primary mechanisms of discharge. Historical pumpage of ground water from beneath the Corcoran Clay Member has lowered the potentiometric surface in the confined zone hundreds of feet over much of the western valley and has lowered the water table beneath parts of the fanheads of the alluvial fans. Percolation of irrigation water past crop roots has caused the water table to rise over a large part of the western valley since 1952. Surface-water deliveries from the California Aqueduct have caused a decrease in pumpage since 1967 and a consequent recovery in hydraulic head throughout the aquifer system.

Increased recharge by percolation of irrigation water past crop roots and historical pumpage of ground water from beneath the Corcoran Clay Member have created a ground-water divide in the western part of the valley. The divide is more or less parallel with the Coast Ranges but is closer to the Coast Ranges in fine-textured interfan areas and farther from the Coast Ranges in coarse-textured fanhead areas. The combination of percolation and pumpage also has resulted in development of a downward component of flow in the semiconfined zone. This downward component of flow is decreasing over time in response to reduced pumping. The present-day flow system is in a transient state and is adjusting to stresses placed upon it in both the past and present.

\section{REFERENCES CITED}

Blissenbach, Erich. 1954, Geology of alluvial fans in semiarid regions: Geological Society of America Bulletin, v. 65, no. 2. p. $175-189$.

Bull, W.B., 1964a, Geomorphology of segmented alluvial fans in western Fresno County. California: U.S. Geological Survey Professional Paper 352-E, 129 p.

_ 1964b, Alluvial fans and near-surface subsidence in western Fresno County. California: U.S. Geological Survey Professional Paper 437-A, 71 p.

1972. Prehistoric near-surface subsidence cracks in western
Fresno County. California: U.S. Geological Survey Professional Paper 437-C, 85 p.

1975, Land subsidence due to ground-water withdrawal in the Los Banos-Kettleman City area, California-Pt. 2, Subsidence and compaction of deposits: U.S. Geological Survey Professional Paper 437-F, 90 p.

Bull, W.B., and Miller, R.E., 1975, Land subsidence due to ground-water withdrawal in the Los Banos-Kettleman City area, California-Pt. 1, Changes in the hydrologic environment conducive to subsidence: U.S. Geological Survey Professional Paper 437-E, 71 p.

California Division of Mines and Geology, 1959, Geologic map of California, Santa Cruz sheet: California Department of Conservation, 2 sheets, scale 1:250,000.

_ 1965, Geologic map of California, Fresno sheet: California Department of Conservation, 2 sheets, scale 1:250,000.

1966, Geologic map of California, San Jose sheet: California Department of Conservation, 2 sheets, scale 1:250.000.

Croft, M.G., 1972, Subsurface geology of the Late Quaternary water-bearing deposits of the southern part of the San Joaquin Valley, California: U.S. Geological Survey Water-Supply Paper 1999-H, 29 p.

Davis, G.H., Green, J.H., Olmsted, F.H., and Brown, D.W., 1959, Ground-water conditions and storage capacity in the San Joaquin Valley, California: U.S. Geological Survey Water-Supply Paper 1469, 287 p.

Davis. G.H., and Poland, J.F., 1957, Ground-water conditions in the Mendota-Huron area, Fresno and Kings Counties, California, in Contributions to the hydrology of the United States, 1955: U.S. Geological Survey Water-Supply Paper 1360-G, p. $408-588$.

Deverel, S.J., Gilliom, R.J., Fujii, Roger, Izbicki, J.A., and Fields, J.C., 1984, Areal distribution of selenium and other inorganic constituents in shallow ground water of the San Luis drain service area, San Joaquin Valley, California-A preliminary study: U.S. Geological Survey Water-Resources Investigations Report 84 4319, $67 \mathrm{p}$.

Diamond, Jonathan, and Williamson, A.K., 1983, A summary of ground-water pumpage in the Central Valley, California, 1961-77: U.S. Geological Survey Water-Resources Investigations Report 83-4037. $70 \mathrm{p}$.

Hamilton, Fletcher, 1916, Geological map of the State of California: California Division of Mines and Geology, 1 sheet, scale, 1:750,000.

Harradine, F.F., 1950, Soils of western Fresno County: Berkeley, University of California Press, $86 \mathrm{p}$.

Hotchkiss, W.R., 1972, Generalized subsurface geology of the water-bearing deposits, northern San Joaquin Valley, California: U.S. Geological Survey open-file report, $18 \mathrm{p}$.

Hotchkiss, W.R., and Balding, G.O.. 1971, Geology, hydrology, and water quality of the Tracy-Dos Palos area, San Joaquin Valley, California: U.S. Geological Survey open-file report, $107 \mathrm{p}$.

Ireland, R.L., Poland, J.F., and Riley, F.S., 1984, Land subsidence in the San Joaquin Valley, California, as of 1980: U.S. Geological Survey Professional Paper 497-I, 93 p.

Johnson, A.I., Moston, R.P., and Morris, D.A., 1968, Physical and hydrologic properties of water-bearing materials in subsiding areas in central California: U.S. Geological Survey Professional Paper 497-A. 71 p. 
Laudon, Julie, and Belitz, Kenneth, 1989, Texture and depositional history of near-surface alluvial deposits in the central part of the western San Joaquin Valley, California: U.S. Geological Survey Open-File Report 89-235, 19 p.

Mendenhall, W.C., 1908, Preliminary report on the ground waters of the San Joaquin Valley, California: U.S. Geological Survey Water-Supply Paper 222, 53 p.

Mendenhall, W.C., Dole, R.B., and Stabler, Herman, 1916, Ground water in the San Joaquin Valley, California: U.S. Geological Survey Water-Supply Paper 398, 310 p.

Miller, R.E., Green, J.H., and Davis, G.H., 1971, Geology of the compacting deposits in the Los Banos-Kettleman City subsidence area, California: U.S. Geological Survey Professional Paper 497-E, 46 p.

Page, R.W., 1986, Geology of the fresh ground-water basin of the Central Valley, California, with texture maps and sections: U.S. Geological Survey Professional Paper 1401-C, 54 p.

Poland, J.F., Lofgren, B.E., Ireland, R.L., and Pugh, R.G., 1975, Land subsidence in the San Joaquin Valley, California. as of 1972: U.S. Geological Survey Professional Paper $437-\mathrm{H}, 78 \mathrm{p}$

Reineck, H.E., and Singh, I.B., 1980, Depositional sedimentary environments: New York, Springer-Verlag. 552 p.

Tidball, R.R, Severson, R.C., Gent, C.A., and Riddle, G.O., 1986. Element associations in soils of the San Joaquin Valley, California: U.S. Geological Survey Open-File Report $86-583,15 \mathrm{p}$.

U.S. Bureau of Reclamation, 1965, San Luis Unit, Central Valley Project, California-Ground-water conditions and potential pumping resources above the Corcoran Clay, an addendum to Ground-water geology and resources definite plan appendix 1963: 7 p., 21 pls.

Williamson, A.K., 1982, Evapotranspiration of applied water, Central Valley, California, 1957-78: U.S. Geological Survey Water-Resources Investigations Report 81-45, 56 p.

Williamson, A.K., Prudic, D.E., and Swain, L.A., 1989, Ground-water flow in the Central Valley, California: U.S. Geological Survey Professional Paper 1401-D, 127 p. 


\section{SELECTED SERIES OF U.S. GEOLOGICAL SURVEY PUBLICATIONS}

\section{Periodicais}

Earthquakes \& Volcanoes (issued bimonthly). Preliminary Determination of Epicenters (issued monthly).

\section{Technical Books and Reports}

Professional Papers are mainly comprehensive scientific reports of wide and lasting interest and importance to professional scientists and engineers. Included are reports on the results of resource studies and of topographic, hydrologic, and geologic investigations. They also include collections of related papers addressing different aspects of a single scientific topic.

Bulletins contain significant data and interpretations that are of lasting scientific interest but are generally more limited in scope or geographic coverage than Professional Papers. They include the results of resource studies and of geologic and topographic investigations; as well as collections of short papers related to a specific topic.

Water-Supply Papers are comprehensive reports that present significant interpretive results of hydrologic investigations of wide interest to professional geologists, hydrologists, and engineers. The series covers investigations in all phases of hydrology, including hydrogeology, availability of water, quality of water, and use of water.

Circulars present administrative information or important scientific information of wide popular interest in a format designed for distribution at no cost to the public. Information is usually of short-term interest.

Water-Resources Investigations Reports are papers of an interpretive nature made available to the public outside the formal USGS publications series. Copies are reproduced on request unlike formal USGS publications, and they are also available for public inspection at depositories indicated in USGS catalogs.

Open-File Reports include unpublished manuscript reports, maps, and other material that are made available for public consultation at depositories. They are a nonpermanent form of publication that may be cited in other publications as sources of information.

\section{Maps}

Geologic Quadrangle Maps are multicolor geologic maps on topographic bases in 7 1/2-or 15 -minute quadrangle formats (scales mainly 1:24,000 or 1:62,500) showing bedrock, surficial, or engineering geology. Maps generally include brief texts; some maps include structure and columnar sections only.

Geophysical Investigations Maps are on topographic or planimetric bases at various scales; they show results of surveys using geophysical techniques, such as gravity, magnetic, seismic, or radioactivity, which reflect subsurface structures that are of economic or geologic significance. Many maps include correlations with the geology.

Miscellaneous Investigations Series Maps are on planimetric or topographic bases of regular and irregular areas at various scales; they present a wide variety of format and subject matter. The series also includes 7 1/2-minute quadrangle photogeologic maps on planimetric bases which show geology as interpreted from aerial photographs. Series also includes maps of Mars and the Moon.
Coal Investigations Maps are geologic maps on topographic or planimetric bases at various scales showing bedrock or surficial geology, stratigraphy, and structural relations in certain coal-resource areas.

Oll and Gas Investigations Charts show stratigraphic information for certain oil and gas fields and other areas having petroleum potential.

Miscellaneous Field Studies Maps are multicolor or black-andwhite maps on topographic or planimetric bases on quadrangle or irregular areas at various scales. Pre-1971 maps show bedrock geology in relation to specific mining or mineral-deposit problems; post-1971 maps are primarily black-and-white maps on various subjects such as environmental studies or wilderness mineral investigations.

Hydrologic Investigations At lases are multicolored or black-andwhite maps on topographic or planimetric bases presenting a wide range of geohydrologic data of both regular and irregular areas; principal scale is $1: 24,000$ and regional studies are at $1: 250,000$ scale or smaller.

\section{Catalogs}

Permanent catalogs, as well as some others, giving comprehensive listings of U.S. Geological Survey publications are available under the conditions indicated below from the U.S. Geological Survey, Books and Open-File Reports Section, Federal Center, Box 25425, Denver, CO 80225. (See latest Price and Availability List.)

"Publications of the Geological Survey, 1879-1961" may be purchased by mail and over the counter in paperback book form and as a set of microfiche.

"Publications of the Geological Survey, 1962-1970" may be purchased by mail and over the counter in paperback book form and as a set of microfiche.

"Publications of the U.S. Geological Survey, 1971- 1981" may be purchased by mail and over the counter in paperback book form (two volumes, publications listing and index) and as a set of microfiche.

Supplements for 1982, 1983, 1984, 1985, 1986, and for subsequent years since the last permanent catalog may be purchased by mail and over the counter in paperback book form.

State catalogs, "List of U.S. Geological Survey Geologic and Water-Supply Reports and Maps For (State)," may be purchased by mail and over the counter in paperback booklet form only.

"Price and Avallability List of U.S. Geological Survey Publications," issued annually, is available free of charge in paperback booklet form only.

Selected copies of a monthly catalog "New Publications of the U.S. Geological Survey" available free of charge by mail or may be obtained over the counter in paperback booklet form only. Those wishing a free subscription to the monthly catalog "New Publications of the U.S. Geological Survey" should write to the U.S. Geological Survey, 582 National Center, Reston, VA 22092.

Note.--Prices of Government publications listed in older catalogs, announcements, and publications may be incorrect. Therefore, the prices charged may differ from the prices in catalogs, announcements, and publications. 